\title{
Public Principle and Private Choice: The Uneasy Case for a Boundary Maintenance Theory of Constitutional
}

Law

\section{Louis Michael Seidman†}

During the Lochner era, ${ }^{1}$ the Supreme Court often acted as if constitutional adjudication were a process by which it discovered a "natural" boundary between inherently "public" and "private" spheres." This conception of constitutional law has not recovered-and probably never will recover-from the sustained and devastating assault by the Legal Realists. $^{3}$ Today, few would argue that the boundary between public and private is in any way "natural." To the extent that it exists at all, the boundary is a human construct that must be fought for and quarreled over. Moreover, the widespread interpenetration of activities formerly thought to be "public" or "private," as well as the growing implausibility of right-privilege ${ }^{5}$ and malfeasance-nonfeasance ${ }^{6}$ distinctions, have made it

$\dagger$ Professor of Law, Georgetown University Law Center. Research for this article was supported by grants from the Project on the Federal Social Role and the Georgetown University Law Center. I owe a special debt of gratitude to Cass Sunstein and Paul Gewirtz, who spent many hours reviewing an carlier draft. I am also grateful to Judith Areen, Richard Brandt, Frank Cassel, Peter Edelman, E. Donald Elliott, Colin Greer, Thomas Krattenmaker, Deborah Malamud, Robert Pitofsky, Warren Schwartz, Girardeau Spann, Geoffrey Stone, Mark Tushnet, Silas Wasserstrom, and Nicholas White for their helpful criticism. Valuable research assistance was provided by Linda Lauve and Regina Maloney.

This Article is for Lisa Goldfluss.

1. Lochner v. New York, 198 U.S. 45 (1905).

2. For a survey of the era, see G. Stone, L. Seidman, C. Sunstein \& M. Tushnet, ConstiTUTIONAL LAw 739-41 (1986) [hercinafter Constitutional LAW].

3. For representative examples of Realist criticism of formalistic reasoning, see K. LLEWELLYN, The Common Law Tradition: Deciding appeals 3-18, 393 (1960); Fuller, American Legal Realism, 82 U. PA. L. REv. 429, 435-38 (1934). See generally Tushnet, Post-Realist Legal Scholarship, 1980 Wis. L. REv. 1383, 1384-88.

4. See, e.g., Kreimer, Allocational Sanctions: The Problem of Negative Rights in a Positive State, 132 U. PA. L. REv. 1293, 1294-96 (1984) (questioning distinction between "negative" and "positive" rights); $c f$. Nebbia v. New York, 291 U.S. 502, 531-34 (1934):

But we are told that because the law essays to control prices it denies due process . . . .

The argument runs that the public control of rates or prices is per se unreasonable and unconstitutional, save as applied to businesses affected with a public interest . . . [But t]he statement that one has dedicated his property to a public use is . . merely another way of saying that if one embarks in a business which public interest demands shall be regulated, he must know regulation will ensue.

5. See, e.g., Van Alstyne, The Demise of the Right-Privilege Distinction in Constitutional Law, 81 HARV. L. Rev. 1439 (1968).

6. See, e.g., Kreimer, supra note 4, at 1324-26. 
seem increasingly doubtful that the construct has any meaning at all. ${ }^{7}$ And yet, a half century after the interment of Lochner, the Supreme Court continues to bound separate public and private spheres. The project of this Article is to explain this state of affairs. How is constitutional law possible in a post-Lochner world?

In Section I, I argue that the public/private distinction is best understood in terms of three interlocking dilemmas that are at the heart of modern political debate. The first dilemma concerns the relationship between universalist and particularist values. This relationship is problematic: AIthough most of us are drawn to the universalist ideal of equal, disinterested, and impersonal beneficence toward all members of an expansively bounded community, we are also attracted to the particularist ideal of selfregard and caring, intimate relationships premised on preferences for particular members of that community.

The second dilemma concerns the relationship between government intervention and libertarianism. This relationship is also problematic: Although we want a government powerful enough to protect individual autonomy from nongovernment coercion, we also fear that such a government would be powerful enough to destroy the autonomy it is designed to protect.

The third dilemma concerns the relationship between openness and secrecy. Here the problem is that although information is a necessary predicate for autonomous decisionmaking, we sometimes use that autonomy to keep secret intimate details of our private lives.

My aim is not to offer a theory to resolve these three dilemmas. On the contrary, I argue that the nature of these contradictory impulses makes constitutional law necessary. Instead of offering reconciliation, constitutional law allows us to live with contradiction by establishing a shifting, uncertain, and contested boundary between distinct public and private spheres within which conflicting values can be separately nurtured.

Such a boundary is necessary because of the tendency of each sphere to engulf the other. On the one hand, there is constant risk that the public sphere will be co-opted by egocentric individuals who advance particularist values. These efforts must be resisted in order to preserve unifying institutions that foster widespread allegiance and act for the public good. Part of that resistance consists of efforts to keep government institutions sufficiently open to detect and check efforts of capture by narrowly-based factions.

On the other hand, some limits must be set on the jurisdiction of a

7. See Kennedy, The Stages of the Decline of the Public/Private Distinction, 130 U. PA. L. REv. 1349 (1982). 
government kept truly free of private domination. There must be an enforceable boundary between government and nongovernment spheres so that individuals have space to develop the particularist side of their personalities. Just as openness protects the universalist orientation of government, privacy-in the sense of secrecy-protects a particularist sphere by shielding particularist decisions from what could otherwise be destructive criticism from universalist institutions.

The remainder of my argument concerns the special role of judicial review in enforcing the boundary between public and private. Section II argues that most modern theories of judicial review have failed to cope with Legal Realism's legacy. This difficulty stems from a tension in the utilitarian theory that lies at the root of much post-Realist analysis. On the one hand, utilitarianism's bias in favor of universalist values presses us toward an equal regard for the welfare of everyone. ${ }^{8}$ On the other hand, its refusal to make normative judgments concerning tastes and preferences argues against the kind of judicial review that would be necessary to vindicate such equality. The result is a persistent divergence between promise and performance: Whereas many modern constitutional theories seem to argue for vigorous judicial action to promote openness and government protection for universalist values, the Court has opted instead for a form of constitutional review that checks government, and thereby protects a system of exclusive "private" nongovernment institutions blocking equal access to goods and power.

Section III suggests some ways in which these difficulties might be overcome by understanding the interrelationships of the three dilemmas outlined above. The work of judges can be understood as an effort to manipulate decisionmaking contexts through, for example, insistence on varying degrees of openness and secrecy, or government interventionism and libertarianism, so as to preserve continuing, unresolved tensions between our universalist and particularist urges. Judges can be seen as specially equipped to perform this role because of existing institutional arrangements that encourage their mixed allegiance to both universalism and particularism.

To avoid misunderstanding, I want to make clear that this theory of judicial review is not normative, at least not in the usual sense. It is not my intention to advance an argument that requires or compels the reader to accept the legitimacy of modern constitutional review. As Robert Nozick has pointed out, "trying to get someone to believe something

8. This is not to say that all forms of utilitarianism necessarily require equality of outcomes. In some versions of the theory, the very requirement of equal counting of utilities leads to distributions strongly favoring those who can make best use of the resource in question. The theory is nonetheless egalitarian in the sense that it takes as its initial premise the necessity of an equal counting of utilities. 
whether he wants to believe it or not, is not . . a nice way to behave toward someone." Rather, my argument is advanced in the spirit of Nozick's effort to show how certain beliefs are possible. ${ }^{10}$ Only after exploring the best possible reasons why one might want to believe in constitutional review as practiced in this country can we talk about whether one would want to hold such a belief.

In Section IV, I offer tentative thoughts about why one might, or might not, find such a belief attractive. I argue that a boundary maintenance theory resolves some of the anomalies discussed in Section II and assists in understanding some otherwise incomprehensible forms of judicial intervention. But it also creates new problems-problems that are likely to make advocates of the theory uneasy. These problems in turn raise broader questions concerning the limits on what we can realistically expect from a theory of constitutional law.

\section{Public Principle and Private Choice}

At some point during the first third of this century our political discourse about constitutional rights got seriously out of whack. The emergence of this difficulty coincided with the development of a schism in classical liberalism, a schism that tracks the interventionist versus libertarian dilemma. ${ }^{11}$

Liberal thought is characterized in part by the importance it attaches to the individual's autonomy in pursuing her own conception of the good. ${ }^{12}$ The schism concerns the relationship between the performance of government and the protection of autonomy. Libertarians associate autonomy with the absence of governmental coercion. Those suspicious of government define autonomy as the ability of individuals to participate in "free" markets unfettered by government control. ${ }^{13}$ Any inequalities that result from these market transactions are considered just because they emerge from a just process. ${ }^{14}$

In contrast, interventionists see vigorous government redistribution as a precondition to real freedom. Inequalities in the distribution of power and

9. R. Notic:k, Phil.osophical. Expl.Anations 13 (1981).

10. See id. at 8-24.

11. See, e.g., H. Laski, ThE: Drci.ine of Liberalism 6-13 (1940); T. Neill, The Rise and Dect.INE: OF Liberal.ISM 13-32 (1953). Critics of liberal democracy have argued that the schism reflects the internal contradictions in any theory that is both liberal and democratic. See, e.g., A. LeVine, Liberal. Dimosiracy (1981).

12. See, e.g., G. Mort.an, America's Herttage from John Stuart Mill 30-36 (1936); Dworkin, Liberalism, in Publ.r: and Private Morality 113, 127-36 (S. Hampshire ed. 1978).

13. See, e.g., F. Haykk, Thk: Constrtution of Liberty (1960); R. Nozick, ANarchy, STATE, AND U.TOPIA (1974).

14. See, e.g., R. PoSner, The Economics of Justice 60-87 (1981); $c f$. R. Nozick, supra note 13 , at 161-64. 
resources between competing nongovernment groups make the "freedom" to participate in markets to some extent illusory. ${ }^{18}$ Only through a program of collective action can nongovernment coercion be restrained and genuine autonomy guaranteed.

Both of these views are problematic and limited. It would be a serious mistake to suppose that they are the only poles around which our political debate could be organized. It would also be a mistake to suppose that many politicians adhere with unwavering consistency to one view or the other. But both views are coherent ways of looking at the world, and they serve as a useful, if overly simple, means of modeling and understanding modern political dialogue. Unfortunately, however, it has proven extremely difficult to translate either view into a coherent constitutional theory.

\section{A. Interventionist Theory}

It is possible to imagine an interventionist theory of constitutional rights. The government would have a constitutional obligation systematically to correct deficiencies in allocations of goods and power produced by the private sector. This view might be coupled with an activist theory of judicial review under which the Court would insist on government intervention whenever the political branches default in their obligation to regulate private power. ${ }^{16}$ In general, however, the interventionist theory has not prevailed. ${ }^{17}$ Instead, the Court has identified constitutional law with

15. See, e.g., B. Ackerman, Social. Justick. IN ThE Liberai. Statte 261-72 (1980).

16. For some efforts to demonstrate that an interventionist theory is possible, see P. Edelman, $A$ Judicially Declared Right to a Minimum "Survival" Income-An Idea Whose Time May Yet Come (rev. ed. Sept. 1986) (unpublished manuscript); Michelman, Welfare Rights in a Constitutional Democracy, 1979 Wash. U.L.Q. 659; Tushnet, Dia-Tribe (Book Review), 78 Mich. L. REv. 694, 696-701 (1980).

17. This is not to deny the existence of an alternative tradition in American constitutional law. Justice Black spoke for this view in Marsh v. Alabama, 326 U.S. 501 (1946), when he wrote that the state has an affirmative obligation to prevent private corporations from interfering with freedom of speech:

When we balance the Constitutional rights of owners of property against those of the people to enjoy freedom of press and religion, . . . we remain mindful of the fact that the latter occupy a preferred position. ... In our view the circumstance that the property rights to the premises where the deprivation of liberty, here involved, took place, were held by others than the public, is not sufficient to justify the State's permitting a corporation to govern a community of citizens so as to restrict their fundamental liberties....

Id. at 509 (footnote omitted). Similarly, the Court's preoccupation with the effect of school segregation on the "hearts and minds" of black children in Brown v. Board of Educ., 347 U.S. 483, 494 (1954), can be understood as rooted in an affirmative government obligation to arrange its institutions so as to prevent the perpetuation of entrenched hierarchies. See generally Fiss, Groups and the Equal Protection Clause, 5 J. Phil.. \& PuB. Aff. 107 (1976). As the Court noted in Plyler v. Doe, 457 U.S. 202, 218-19 (1982) (footnotes omitted):

Sheer incapability or lax enforcement of the laws barring entry into this country . . . has resulted in the creation of a substantial "shadow population" of illegal migrants-numbering in the millions-within our borders. This situation raises the specter of a permanent caste of 
the task of defining private spheres within which individuals must be left free from government interference. ${ }^{18}$

Two hypothetical cases illustrate the problems this orientation poses for certain strands of modern constitutional scholarship. In the first case, a married couple engages in some form of "nonstandard" sexual activity in the privacy of their own bedroom. In the second case, the couple engages in precisely the same activity in the presence of a film crew that records the event for distribution to local movie houses. For present purposes, there is no need to determine whether the state could interfere with either or both of these activities. ${ }^{10}$ What is significant is that the couple's claim to constitutional protection in the first case would almost certainly be stronger than the claim in the second case. ${ }^{20}$ This difference stems from the fact that the first couple has kept its conduct within a private sphere in a way that the second has not. The first couple could therefore rely on such cases as Griswold $v$. Connecticut ${ }^{21}$ and Stanley $v$. Georgia, ${ }^{22}$ in

undocumented resident aliens, encouraged by some to remain here as a source of cheap labor, but nevertheless denied the benefits that our society makes available to citizens and lawful residents. The existence of such an underclass presents most difficult problems for a Nation that prides itself on adherence to principles of equality under law.

In general, however, this alternative tradition has been subordinated. Compare, e.g., Marsh and Brown with Rendell-Baker v. Kohn, 457 U.S. 830 (1982) (employees asserting unconstitutional discharge did not state claim under 42 U.S.C. $\$ 1983$ merely because employer supported by public funds) and Washington v. Davis, 426 U.S. 229 (1976) (showing of racially disproportionate impact alone is insufficient to trigger heightened scrutiny under equal protection or due process clause). For a discussion of the confusion that is generated when the two traditions clash, see Constitutional. LAW, supra note 2, at 575-78.

18. The modern "state action" doctrine, for example, rests on the premise that people are "free" as long as the government remains passive. See, e.g., Lugar v. Edmondson Oil Co., 457 U.S. 922 , 936-37 (1982):

Careful adherence to the "state action" requirement preserves an area of individual freedom by limiting the reach of federal law and federal judicial power. . . . A major consequence is to require the courts to respect the limits of their own power as directed against ... private interests. Whether this is good or bad policy, it is a fundamental fact of our political order. The unthinking equation of "individual freedom" with limitations on the reach of federal law would be quite congenial to adherents of laissez-faire capitalism. Of course, the architects of Reconstruction and of the New Deal had a different idea. Only a Court profoundly committed to a libertarian version of autonomy could accept the equation as a "fundamental fact of our political order." Id. at 937.

19. Nlthough the Court has upheld application of a sodomy statute to voluntary, private homosexual acts, Bowers v. Hardwick, $106 \mathrm{~S}$. Ct. 2841 (1986), it pointedly distinguished its prior cases concerning state regulation of incidents of the marriage relationship, id. at $2843-44$, and did not consider constitutional questions posed by criminalization of nonhomosexual sodomy. Id. at $2842 \mathrm{n} .2$.

20. In Lovisi v. Slayton, 363 F. Supp. 620 (E.D. Va. 1973), for example, the court rejected a constitutional attack on the sodomy conviction of a married couple because they had arranged to photograph their sexual activity.

The existence of seclusion in a sexual act . . . is a necessary prerequisite to that act's being protected from state regulation by the Constitution. Where that element has been relinquished by the parties in the performance of their sexual act, they have given up the Constitution's protection over the manner in which they choose to carry out that act.

Id. at 626; see also Bowers, $106 \mathrm{~S}$. Ct. at 2855 (Blackmun, J., dissenting) (emphasizing constitutionally significant distinction between "laws that protect public sensibilities and those that enforce private morality").

21. 381 U.S. 479 (1965).

22. 394 U.S. 557 (1969). 
which constitutional protection was premised on the nonpublic nature of the activity. ${ }^{23}$ In Griswold, the Court thought that sexual relations incident to marriage deserved special constitutional protection because marriage is "an association that promotes a way of life, not causes; a harmony in living, not political faiths; a bilateral loyalty, not commercial or social projects." "24 And in Stanley, the Court struck down the state's effort to regulate the private use of pornography because the state was unable to demonstrate that the conduct in question had any public effect: "Whatever the power of the state to control public dissemination of ideas inimical to the public morality, it cannot constitutionally premise legislation on the desirability of controlling a person's private thoughts."25

For adherents to the currently dominant branches of constitutional theory, these results must seem incomprehensible. First Amendment theory suggests that communication is worthy of special protection precisely because it deals with "causes," "political faiths," and "commercial or social projects." Speech is said to "check" government, ${ }^{26}$ or to unblock the channels of change, ${ }^{27}$ or to be essential to the processes of self-government, ${ }^{28}$ or even to epitomize the fundamental human desire to interrelate with other members of the species. ${ }^{29}$ Could the commentators espousing these views possibly be describing the same First Amendment that, the Supreme Court tells us, protects Stanley in his lonely, apolitical, masturbatory fantasies $?^{30}$

23. Cf. Roberts v. United States Jaycees, 468 U.S. 609, 618-22 (1984) (organization lacked distinctive characteristics of smallness or selectivity that might have afforded constitutional protection to its decision to exclude women).

24. 381 U.S. at 486.

25. 394 U.S. at 566.

26. See Blasi, The Checking Value in First Amendment Theory, 1977 AM. B. Found. Res. J. 521.

27. See, e.g., J. El.y, Dimocracy and Distrust 105-34 (1980).

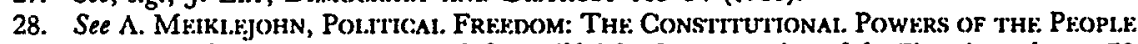
(1965); Brennan, The Supreme Court and the Meiklejohn Interpretation of the First Amendment, 79 Harv. L. Rkv. 1, 11-12 (1965).

29. See I. Briri.IN, John Stuart Mill and the Ends of Life, in Four Essays on Libs:r'T 173 (1969).

30. The tension between Stanley and conventional First Amendment theory recently surfaced in the Court's treatment of the case in Bowers v. Hardwick, $106 \mathrm{~S}$. Ct. 2841 (1986). Hardwick relied on Stanley to support his claim that the state could not constitutionally punish voluntary acts of sodomy performed in his own home. Although the Court acknowledged that Stanley protected conduct that would not have been protected outside the home, it sought to distinguish the case on the ground that Stanley "was firmly grounded in the First Amendment." Id. at 2846. But the Court has never articulated a theory of the First $\Lambda$ mendment that would accord more protection to conduct precisely because it was undertaken in an environment that minimized the possibility of communication with others.

Griswold, unlike Stanley, does not purport to rest on a First Amendment rationale. But it again seems paradoxical that the married couple in Griswold was entitled to more protection because they were not engaged in the kind of public communication ordinarily shielded by the First Amendment. The Griswold Court seems to have been aware of this problem. $\Lambda$ s originally drafted, Justice Douglas's opinion relied expressly on the First Amendment. Douglas argued that the Connecticut anti- 
Broader constitutional theories do not clarify matters. Many of these theories are preoccupied with fostering universalist values. For example, pluralist theories tell us that judicial intervention is necessary to compensate for the effective exclusion of certain groups from the political process. Adherents to these theories argue that the inability of some minorities to form coalitions with other groups prevents political institutions from properly aggregating individual preferences. The exclusion of these groups means that our government institutions do not truly represent the public interest. ${ }^{\text {31 }}$

In recent years, there has been a backlash against pluralist constitu-

contraception statute violated freedom of association by interfering with the marriage relationship, which "flourishes on the interchange of ideas." B. SchwarTz, THE UNPUBLISHED OPINIONS OF THE WARREN COUR' 235 (1985). When Douglas first unveiled this theory at conference, it elicited a biting rejoinder from Justice Black, a Griswold dissenter: "[The r]ight of association is for me [a] right of assembly [and the right] of [a] husband [and] wife to assemble in bed is [a] new right of assembly to me." Id. at 237. Even Justice Brennan, a member of the Grirwold majority, was unpersuaded by the First Amendment rationale. He wrote Douglas that the "association" of married couples had little to do with the public advocacy protected by the freedom of assembly clause. $I d$. Ultimately, Douglas was persuaded to abandon his "interchange of ideas" rationale in favor of an approach based on personal privacy. Id. at 238.

31. In its simplest form, pluralism suggests that outcomes of the political process necessarily reflect the public interest. This theory assumes that the public interest consists of nothing more than the fair aggregation of private preferences and that the political process provides a method of fair aggregation. See, e.g., Becker, A Theory of Competition Among Pressure Groups for Political Influence, 98 Q.J. Econ. 371 (1983). This view supports positivist constitutional theories that treat the Constitution as embodied in whatever outcomes the political process produces. See, e.g., J. ChOPER, Judicial Revifw and rHe. Na'tional. Pol.rtical. Process 29-45 (1980); Thayer, The Origin and Scope of the American Doctrine of Constitutional Law, 7 HARv. L. REv. 129 (1893); Wechsler, The Political Safeguards of Federalism: The Role of the States in the Composition and Selection of the National Government, 54 Col.um. L. Rkv. 543 (1954). See generally Parker, The Past of Constitutional Theory-and Its Future, 42 OHio Sr. L.J. 223, 224-29 (1981). The theory is usually taken to imply a passive judicial stance, see, e.g., J. CHOPER, supra, at 171-379, although it remains far from clear why an activist Court should be excluded from the embodied constitutional order. See Spann, Hyperspace (Book Review), 84 Mrch. L. REv. 628, 638 (1986). This version of pluralism currently dominates the Court's approach to federalism and to "social and economic" legislation. See, e.g., Garcia v. San Antonio Metro. Transit Auth., 469 U.S. 528 (1985); United States R.R. Retirement Bd. v. Fritz, 449 U.S. 166 (1980).

Pluralists who favor some form of judicial activism have generally pointed to a defect in the aggregation process to support judicial intervention. The currently dominant version of the theory focuses on "discrete and insular" minorities precluded by prejudice from entering into coalitions with other groups. See United States v. Carolene Prods. Co., 304 U.S. 144, 153 n.4 (1938). See generally infra text accompanying notes 117-48. For the now classic synthesis, see J. ELY, supra note 27. Other versions of the theory focus on "free rider" problems, which may prevent disorganized and widely dispersed groups from effective political participation, see, e.g., R. Hardin, Collective Action (1982); G. Wilson, InTERest Groups in The UnIted States (1981); Ackerman, Beyond Carolene Products, 98 HaRv. L. Rkv. 713, 724-28 (1985), or on contradictions inherent in any "democratic" voting procedure, see, e.g., A. Fridman, Welfare Economics and Social Choice Theory (1980). See generally J. Buchanan \& G. Tullock, The Calculus of Consent (1962); D. Muet.l.ter, Pubt.lc: Chorce: (1979).

Pluralists with an interventionist bias have used the "defect" approach to support selective judicial action to "cleanse" the political process by protecting powerless minorities from hostile legislation. See generally Cover, The Origins of Judicial Activism in the Protection of Minorities, 91 YALE L.J. 1287 (1982). Libertarian versions of the theory use some of the same observations to argue for market allocations. See, e.g., B. Sircian, Economic Liberties AND the Constitution 318-31 (1980). 
tional theory. But ironically, the critique asserts that pluralist theory is insufficiently universalist. Nonpluralists assert that the public interest is more than the simple aggregation of private preferences. Indeed, legislation that reflects no more than private preferences-"special interest legislation"-should be unconstitutional. The Constitution fosters a public dialogue in which citizens, motivated by civic virtue, transcend narrow private interests and take their public responsibilities seriously. ${ }^{32}$ Judicial review should promote this dialogue by reminding us of values formulated during those occasional dramatic points in our history when public politics were all-consuming. ${ }^{\text {s3 }}$

Meanwhile, apparently oblivious to all of this, the Supreme Court continues to protect a nongovernmental sphere precisely because this sphere is thought to develop the particularist ideals of intimacy and special caring. ${ }^{34}$ Decisions regarding child rearing, ${ }^{35}$ procreation, ${ }^{36}$ religious practice, ${ }^{37}$ and family organization ${ }^{38}$ have all been held to be within this nongovernmental sphere.

It is important to understand, however, that equal protection and free speech jurisprudence, which one might think is more amenable to analysis in terms of pluralist or public interest models, also are examples of the Court's insistence on protection of nongovernmental power. With only rare exceptions, ${ }^{39}$ the Court has not read the equal protection clause to

32. See, e.g., Ackerman, supra note 31, at 713; Michelman, Politics and Values or What's Really Wrong with Rationality Review?, 13 CREIGHron L. REv. 487 (1979); Sunstein, Interest Groups in American Public Law, 38 STAN. L. Rkv. 29 (1985) [hereinafter Interest Groups]; Sunstein, Naked Preferences and the Constitution, 84 CoI.UM. L. REv. 1689 (1984) [hereinafter Naked Preferences].

33. See Ackerman, The Storrs Lectures: Discovering the Constitution, 93 Yal.: L.J. 1013, 1049-52 (1984) (lessons from founding of nation, Civil War, and New Deal "control the meanings we give to our present constitutional predicaments").

34. See Roberts v. United States Jaycees, 468 U.S. 609, 617-19 (1984) (citations omitted): [C] hoices to enter into and maintain certain intimate human relationships must be secured against undue intrusion by the State because of the role of such relationships in safeguarding the individual freedom that is central to our constitutional scheme. . .

Without precisely identifying every consideration that may underlie this type of constitutional protection, we have noted that certain kinds of personal bonds have played a critical role in the culture and traditions of the Nation by transmitting shared ideals and beliefs; they thereby foster diversity and act as critical buffers between the individual and the power of the State. . . . Moreover, the constitutional shelter afforded such relationships reflects the realization that individuals draw much of their emotional enrichment from close ties with others. Protecting these relationships from unwarranted state interference therefore safeguards the ability independently to define one's identity that is central to any concept of liberty.

35. See, e.g., Parham v. J.R., 442 U.S. 584 (1979); Smith v. Organization of Foster Families, 431 U.S. 816 (1977); Stanley v. Illinois, 405 U.S. 645, 651 (1972).

36. See, e.g., Carey v. Population Servs. Int'l, 431 U.S. 678 (1977); Roe v. Wade, 410 U.S. 113 (1973).

37. See, e.g., Widmar v. Vincent, 454 U.S. 263 (1981); Wisconsin v. Yoder, 406 U.S. 205 (1972).

38. See, e.g., Zablocki v. Redhail, 434 U.S. 374 (1978); Moore v. City of East Cleveland, 431 U.S. 494 (1977).

39. See, e.g., Terry v. Adams, 345 U.S. 461 (1953); Shelley v. Kraemer, 334 U.S. 1 (1948); see also supra note 17 (discussing governmental intervention in equal protection cases). 
mandate government intervention to counterbalance nongovernmental arrangements that disadvantage minorities. ${ }^{40}$ The requirement of equal protection has instead been read almost exclusively as a limit on government intervention. Similarly, the First Amendment, in the Court's view, prevents, rather than requires, government regulation of the media even when the regulation is intended to insure that all views in fact compete equally in the free market of ideas. ${ }^{41}$ Indeed, most modern constitutional law can be reduced to a series of rules prohibiting government interference with nongovernmental power centers. A wide variety of nongovernmental institutions-newspapers, ${ }^{42}$ corporations, ${ }^{43}$ families, ${ }^{44}$ churches, ${ }^{45}$ and medical organizations, ${ }^{48}$ to name a few-have benefited from this immunity from government regulation exercised in the name of the public interest. And in the area of criminal procedure, even these organizations may not be sufficiently individualistic to merit constitutional protection. The Court has repeatedly emphasized that the Fourth and Fifth Amendments protect only the lone individual barricaded within the confines of his private dwelling. As soon as he steps out into the world-to form a business, ${ }^{47}$ make a friend, ${ }^{48}$ or even find a spouse ${ }^{48}$-he is said to have lost his "reasonable expectation of privacy." "80

Clearly, then, something is amiss. Whatever the normative merits of their proposals, many modern constitutional theorists are simply not describing what is going on.

40. For example, the Court's seminal decision in Washington v. Davis, 426 U.S. 229 (1976), can be read as establishing the proposition that the government has no affirmative obligation to counteract nongovernmental forces that produce outcomes severely disadvantageous to powerless minorities. See infra text accompanying notes 143-45. Much of the Court's "state action" jurisprudence reflects the same proposition. See Consrriurional. Law, supra note 2, at 1492-94, 1534-36.

41. See, e.g., Pacific Gas \& Elec. Co. v. Public Utils. Comm'n, 106 S. Ct. 903 (1986); Miami Herald Publishing Co. v. Tornillo, 418 U.S. 241 (1974).

42. See, e.g., Nebraska Press Ass'n v. Stuart, 427 U.S. 539 (1976); Miami Herald Publishing Co. v. Tornillo, 418 U.S. 241 (1974); New York Times v. United States, 403 U.S. 713 (1971).

43. See, e.g., Consolidated Edison Co. v. Public Serv. Comm'n, 447 U.S. 530 (1980); First Nat'l Bank v. Bellotti, 435 U.S. 765 (1978).

44. See supra notes $35,38$.

45. See, e.g., NLRB v. Catholic Bishop, 440 U.S. 490 (1979).

46. See Akron v. Akron Center for Reproductive Health, 462 U.S. 416 (1983); $c f$. Colautti v. Franklin, 439 U.S. 379, 396-97 (1977) (state regulation that impinges on determination of fetal viability must allow physician leeway to make best medical judgment).

47. See, e.g., Bellis v. United States, 417 U.S. 85 (1974); Shapiro v. United States, 335 U.S. 1 (1948).

48. See, e.g., Hoffa v. United States, 385 U.S. 293, 303 (1966); Lopez v. United States, 373 U.S. 427, 465 (1963) (Brennan, J., dissenting).

49. See, e.g., Coolidge v. New Hampshire, 403 U.S. 443, 487 (1971); cf. United States v. Matlock, 415 U.S. 164, 171 (1974).

50. See Seidman, ABSCAM and the Constitution, 83 Mich. L. REv. 1199, 1202-03 (1985). 


\section{B. Libertarian Theory}

There is a competing tradition in constitutional scholarship which is devoted to justifying the preservation of a nongovernmental sphere. Adherents to this tradition, although united by opposition to at least certain forms of government coercion, differ radically in the forms of coercion they oppose and the reasons for their opposition. One school in this tradition emphasizes the importance of unfettered participation in private markets, either because gains from trade in such markets will maximize welfare $^{51}$ or because participation in such markets is directly equated with freedom. ${ }^{52}$ A different school views constitutional analysis as reasoned elaboration of natural law theory. ${ }^{53}$ Since the fundamental purpose of government is the protection of natural rights, government coercion that invades these rights is ultra vires.

Whatever the particular permutations of these theories, they have some significant advantages over the interventionist theories described in the previous section. In the first place, if the theories are correct, they at least do the work that is claimed for them; they justify government nonintervention in a private sphere. As argued above, ${ }^{54}$ the same cannot be said for theories emphasizing public values. Moreover, these libertarian theories more successfully resolve the anomaly of judicial review than do their competitors. Public accountability is hardly served by giving more power to our least publicly accountable institution. But if our aim is the preservation of a private sphere, judicial review makes more sense. ${ }^{65}$ Finally, these theories have undeniable roots in the structure of the Constitution and eighteenth century political theory from which it emerged. ${ }^{58}$

Despite their advantages, however, these theories are unlikely to be attractive for many who remember the lessons of the Lochner era. My intention in what follows is to outline briefly some of the reasons why many of us find the theories unattractive, so as to lay the groundwork for a different approach. ${ }^{\mathrm{Bz}}$

Perhaps the most serious deficiency of libertarian theories is the weight

51. See, e.g., R. Posner, Economic: Anal.ysis of LAw 497-502 (2d ed. 1977).

52. See, e.g., B. Sitcian, supra note 31.

53. See, e.g., R. Dworkin, TAkinc; Richts Striousi.y 131-49 (1978); M. Prrky, Tht ConSTITUTION, T'HF: CoUR'IS, AND HUMAN RIGHIS 97-145 (1982); Richards, Interpretation and Historiography, 58 S. CAI.. L. Rkv. 490 (1985).

54. See supra text accompanying notes 31-50.

55. By limiting the power of other branches to intervene in the private sphere, courts ensure that individuals can make some decisions that are not subject to political control. The relative political insulation of the judges themselves buttresses their ability to perform this function.

56. See, e.g., R. Epsthin, Takings: Private: Property and the: Powkr of Eminentr DoMAIN 7-18 (1985).

57. What follows is not intended as a thorough critique of the theories, and I do not pretend that what I have to say about them is either especially original or sufficiently detailed to convert their adherents. 
they place on our ability to distinguish between government "action" that interferes with a private sphere and government "inaction" or neutrality that preserves freedom within that sphere. A familiar illustration is provided by Miller $v$. Schoene, ${ }^{68}$ a decision that in some ways marked the beginning of the end of the Lochner era. In order to prevent infection of apple trees by cedar rust (an organism that destroys apple trees but has no effect on cedars), the state ordered appellants to destroy their cedar trees. This state "intervention" might have been seen as government "action" invading the private sphere, and therefore bearing the burden of justification. But Justice Stone, writing for the Court, viewed the matter differently:

[T] ]he state was under the necessity of making a choice between the preservation of one class of property and that of the other wherever both existed in dangerous proximity. It would have been none the less a choice if, instead of enacting the present statute, the state, by doing nothing, had permitted serious injury to the apple orchards within its border to go on unchecked. When forced to such a choice the state does not exceed its constitutional powers by deciding upon the destruction of one class of property in order to save another which, in the judgment of the legislature, is of greater value to the public. ${ }^{6 \theta}$

Once the decision to do nothing was, itself, seen as government "action" for which the government bore responsibility, it became difficult to understand how people could be treated as "free" when coerced by forces in the private sphere-or, indeed, what made that sphere "private" given the government's choice to allow the coercion to go unchecked. Far from restricting freedom, government intervention became a necessary predicate for it. For example, in a later case the court concluded that government intervention was necessary to end the "exploitation of a class of workers who are in an unequal position with respect to bargaining power and are thus relatively defenseless against the denial of a living wage." ernment's "action" allowing this exploitation to remain unchecked became not simply an act of "neutrality," but "what is in effect a subsidy for unconscionable employers."

Moreover, even if we ignore the problem of private coercion and accept the link between government nonintervention and individual rights, we still face important difficulties in cases where the scope of individual

\footnotetext{
58. 276 U.S. 272 (1928).

59. Id, at 279 .

60. West Coast Hotel Co. v. Parrish, 300 U.S. 379, 399 (1937) (upholding state law establishing minimum wage for women against due process clause attack).

61. Id.
} 
rights is contested. Libertarians value individual freedom and distrust collective decisions. But in the absence of a noncontroversial theory of natural rights, any resolution of the argument about the appropriate boundaries of a nongovernmental sphere will inevitably involve some form of collective intervention and coercion directed against people with a competing theory. Libertarian theories thus constantly teeter on the edge of selfcontradiction. Worse yet, to the extent that libertarians are advocating constitutional theories, they must explain why conflicts over the content of natural rights should be resolved by judges, rather than by political institutions that aggregate all citizens' views on the subject. ${ }^{62}$

Finally, even if collective decisionmaking were avoidable, libertarians would still need to defend their opposition to such decisionmaking. At this point, libertarian theories are vulnerable to recent "civic virtue" theories of constitutional law. ${ }^{63}$ These theories challenge the assumption that individual choices in private markets are the only forms of autonomous choice. Individuals are not merely selfish profit maximizers. They also have altruistic and collective impulses. Thus, even if individuals act autonomously when they participate in private markets, they also act autonomously when they participate in collective institutions that limit those markets. Indeed, our fundamental values can be articulated best when as public citizens we attempt to define the public interest by participating in collective institutions. Public and private markets suffer from different kinds of "market failure," but civic virtue theorists see no inherent reason to take private markets as the baseline with the burden of proof upon those who favor collective action. On the contrary, the theory of the Constitution was that the institutions it established would produce public policy that transcended narrow self-interest. ${ }^{04}$

62. Professor Perry's effort to deal with this difficulty ends in a form of contradiction that is especially instructive. Perry attempts to justify judicial review on the theory that Americans believe in objectively "right" answers to political-moral questions. M. PERRY, supra note 53, at 102. Political institutions, he argues, cannot be relied upon to formulate "right" answers because they are likely to respond by "reflexive reference to the established moral conventions." Id. at 100. Perry must concede that courts can, and on occasion do, give the wrong "right" answers to moral questions. Id. at 115. But we need not fear the prospect of unfettered "false prophecy," he tells us, because the courts' constitutional policymaking "is subject to important control at the hands of electorally accountable officials" and that "consequently, noninterpretive review operates in a manner . . . that accommodates the principle of electorally accountable policymaking." Id. at 126. But surely it is a mistake to suppose that we can have it both ways. One cannot simultaneously advocate judicial review on the ground that it is important to have a system of institutionalized prophecy freed from the constraints of "established moral conventions" and then defend its legitimacy on the ground that it is subject to those constraints.

63. See, e.g., Ackerman, supra note 33; Michelman, Political Markets and Community SelfDetermination: Competing Judicial Models of Local Government Legitimacy, 53 IND. L.J. 145 (1977-1978); Naked Preferences, supra note 32.

64. Much recent scholarship has focused on the role of "civic virtue" and "deliberative politics" in the anti-federalist critique of the Constitution and in the Federalist response. For useful summaries of the evidence, see G. Wit.s, ExPI.AINING AMkrica 177-264 (1981); Ackerman, supra note 33, at 


\section{G. The Constitution and Private Choice}

When the civic virtue critique is coupled with post-Lochner skepticism about the "natural" private sphere and the government "neutrality" paradigm, efforts to defend libertarian theories of judicial review appear doomed. Yet much of the Court's modern work and much of our shared understanding of what constitutional law is all about are nonetheless premised on some such theory. ${ }^{65}$ In this section, I advance an alternative approach that is at once more plausible in the post-Lochner world than competing libertarian theories and more closely tied to the actual role of modern constitutional review than interventionist accounts. Briefly stated, the theory argues that judicial review is necessary to maintain an enforceable boundary between spheres, within which we can play out our separate and contradictory public and private lives.

Before setting out the theory in greater detail it is necessary to be more precise concerning the meanings of "public" and "private." The distinction between the two spheres is associated with three subsidiary distinctions: between universalism and particularism, between interventionism and libertarianism, and between openness and secrecy. It is striking how these three seemingly separate distinctions are associated with common usage of the words "public" and "private." Moreover, the Court seems to understand, at least on an intuitive level, that the three distinctions are linked to each other. ${ }^{86}$ The connections between them are not obvious, however, and need to be explored in some detail.

\section{Universalism Versus Particularism}

By universalism, I mean an insistence that we treat all members of an expansively bounded community with equal concern and respect. Although this requirement is the predicate for virtually all ethical theories, it is especially important for utilitarianism, which insists that we measure the rightness of actions or rules on the basis of everyone's utility and through a system of aggregation that counts utilities of individuals

1017-1031; Interest Groups, supra note 32, at 35-48.

65. See supra text accompanying notes 34-50.

66. In Roberts v. United States Jaycees, 468 U.S. 609 (1984), for example, the Court catalogued the kinds of activity entitled to "privacy" in the sense of government nonintervention. High on its list were the "creation and sustenance of a family," id. at 619 , which was entitled to protection because it fostered particularist values: "Family relationships, by their nature, involve deep attachments and commitments to the necessarily few other individuals with whom one shares not only a special community of thoughts, experiences, and beliefs but also distinctively personal aspects of one's life." Id. at 619-20. Significantly, the Court also associated particularism and nonintervention with secrecy and exclusiveness in the protected relationship: "Among other things, [relationships protected from government intervention] are distinguished by such attributes as relative smallness, a high degree of selectivity in decisions to begin and maintain the affiliation, and seclusion from others in critical aspects of the relationship." Id. at 620; see also infra text accompanying notes 85-92. 
equally ${ }^{67}$ Both universalism and utilitarianism require us to live our lives with public regard, in the sense of universal beneficence toward all members of the public.

While universalists are surely onto an important truth, it is not the only truth. One can perhaps see this most clearly by imagining a universalist saint. As Peter Singer has argued, rigid adherence to universalist values would require a life devoted to serving others. A perfect universalist would give away his goods until the point at which their marginal utility for him would be as great as their marginal utility for another person to whom the goods might be transferred. ${ }^{68}$ Moreover, a universalist saint would avoid not only preference for himself, but also any preference for others that failed to treat the utility of every individual equally. Preference for particular friends, family members, fellow citizens, or even, Singer tells us, fellow homo sapiens would be impermissible. ${ }^{68}$

Such universal beneficence may, in some ways, be an admirable goal. Given our natural tendency toward selfishness, insistence on the goal may be utility maximizing. If any of us ever actually achieved the goal, however, our lives would be fundamentally incomplete. The very factors that make the saint universalist make his beneficence starkly impersonal and disembodied. ${ }^{70}$ Such a saint must care about everyone in the abstract, but no one in particular, because particular caring would involve unequal counting of utilities. In short, a universalist saint would be unable to form a love relationship. He would be an entirely public person. ${ }^{11}$

For present purposes, it matters little whether some version of universalism might be able to take account of these objections. Utilitarians, for

67. " $\Lambda \mathrm{ct}$ utilitarians" believe that an act is morally permissible if, but only if, the total expected utility for everyone affected by it is at least as great as that from any alternative act open to the agent. See R. BRAND', A THrory of THE: GoOD AND THE Right 271 (1979). "Rule utilitarians" would permit performance of an act if, but only if, it is not proscribed by a moral code the currency of which would produce at least as high an expected utility as the currency of any other moral code. See Brandt, A Utilitarian Theory of Excuses, 78 PHIL.. Rkv. 337, 346 (1969). For an introduction to some of the complexities of the theory, see D. LYONS, FORMS AND LimrTS OF UTIIITARIANISM (1965); D.

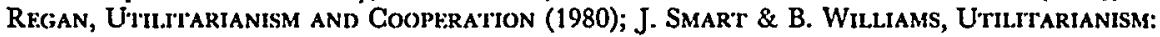
For AND AGaINST (1973).

68. See Singer, Famine, Affluence, and Morality, 1 Phil. \& Puв. Aff. 229 (1972).

69. See Singer, All Animals Are Equal, in Animai. Rights and Human Obligations 148 (T. Regan \& P. Singer eds. 1976).

70. Herder wrote that

[t] he savage who loves himself, his wife and his child . . . and works for the good of his tribe as for his own . . . is in my view more genuine than that human ghost, the . . citizen of the world, who, burning with love for all his fellow ghosts, loves a chimera. The savage in his hut has room for any stranger. . . The saturated heart of the idle cosmopolitan is a home for no one.

W, Herder, Ineas for a Philosophy of the History of Mankind bk. VIII, at 5 , quoted in J. Dunn, Whisikern Poilitical. Thkory in the Face of the Future 77 (1979).

71. Nonutilitarians regularly attack utilitarian theory on these grounds. See, e.g., C. FRIED, AN ANatomy of Val.urs 207-36 (1970); W. Ross, The. Right and the Good 17-19 (1930). 
example, have devoted great energy and ingenuity to devising modifications of their theory so as to incorporate the intuition that private lives and individualized love are important. ${ }^{72}$ Even most utilitarians have that intuition, and any political or moral theory must in some way take account of it. Any theory about what constitutes the good life must recognize that people are both private and public regarding. We are all equal and entitled to equality of concern and respect, but we also need lovers, families, and friends for whom we care specially. Any effort to resolve this contradiction is fundamentally misguided. Any resolution would deny an important aspect of our personalities. We must therefore hold these contradictory impulses in dynamic tension without allowing either to pull us to one pole or the other.

Two examples, both posing excruciatingly difficult conflicts between public and private obligations, illustrate the point. Many white liberals who favor integrated education in theory nevertheless send their own children to nearly all-white schools. Opponents of school integration use this fact with great rhetorical effect to demonstrate the hypocrisy of the liberal position. But a more charitable explanation is possible. White liberals who publicly support integration but privately opt for segregation could be described as demonstrating the inevitable conflict between the universal and particular parts of their personality.

Similarly, some people who publicly proclaim the absolute sanctity of human life and the moral impermissibility of killing might nonetheless take affirmative action to end the hopeless, unbearable suffering of someone they loved. There is a line between admirable adherence to principle and heartless fanaticism, and a person who worries about crossing it undermines neither his public nor private position. Of course, the precise location of the line can be fairly debated. Not all opponents of euthanasia who stick to their principles are heartless fanatics. But neither do all those who waiver from their principles when confronted with hard cases thereby abandon the moral high ground.

We are likely to attempt to resolve this kind of inconsistency in one of two ways. Either we condemn the inconsistent behavior as hypocritical and selfish, or we look for some overarching, reconciling principle that explains it. Unfortunately, both efforts to domesticate the contradiction oversimplify the problem.

Sometimes inconsistent behavior involves mere hypocrisy. An individual

72. For efforts by classical utilitarians to deal with the problem, see J. MrLt, Utilitarianism, in The: Philosophy of John Stuaril Mil. 342-44 (M. Cohen ed. 1961); H. Sidgwick, The METHODS OF ErHICS 252 (1907). I argue below that the attempt to offer universalist justifications for particularist values is fundamentally misguided because, by making the values contingent on satisfying universalist criteria, it denies their particularist character. See infra text accompanying notes 82-83. 
who insists that others live by rules he is unwilling to obey is not admirable. Thus, the white liberal who merely pretends to work for policies that he secretly subverts, and the euthanasia opponent who sanctimoniously condemns others while hiding her own "murder," deserve nothing but contempt. But "hypocrisy" does not quite capture the actions of a white liberal who works hard and in good faith in the political sphere to bring about results that will make it difficult to vindicate her private preferences. Nor can an opponent of euthanasia who kills, but then willingly submits to punishment and publicly acknowledges the wrongfulness of her own conduct, be summarily dismissed as a hypocrite.

It is similarly reductionist to attempt to reconcile the conflicting positions. There may be something special about the educational needs of a particular child or the suffering of a particular terminally ill patient that justifies an exception to the general rule. Moreover, even if an exception were not justified, the demands of consistency might force the integrationist or the euthanasia opponent to modify either her public or private stances when confronted with the contradiction between them. But things do not always work out that way. Some of our preferences are simply inconsistent and context dependent. Sometimes in a moment of private crisis we take actions that we authentically regret once our public stance is restored-but that we would nonetheless take again if returned to the private context.

There is a large body of social science evidence demonstrating that people often maintain irreducibly contradictory and context dependent preferences. ${ }^{73}$ Moreover, it is possible for people to have second-order preferences about the appropriate context. ${ }^{74}$ Indeed, were this not true, the very

\footnotetext{
73. As $\Lambda$ rthur Maas pointed out twenty years ago:

Each individual plays a number of roles in his life . . . and each role can lead him to a unique response to a given choice situation. Thus an individual has the capacity to respond in a given case, to formulate his preferences, in several ways, including these two: (1) what he believes to be good for himself-largely his economic self-interest, and (2) what he believes to be good for the political community. . . .

... [T]he response that an individual gives in any choice situation will depend in significant part on how the question is asked of him, and this means not simply the way a question is worded, but the total environment in which it is put and discussed.

Maas, Benefit-Cost Analysis: Its Relevance to Public Investment Decisions, 80 Q.J. EcoN. 208, 216 (1966). Social scientists have repeatedly demonstrated that people respond differently depending upon whether they are asked to decide in a collective or individual context. See, e.g., Charters \& Newcomb, Some Attitudinal Effects of Experimentally Increased Salience of a Membership Group, in G. SwaNson, T. Nrwcomb \& E. Har'ti.ty, Rradincs in Social. Psychology 415-20 (1958). See generally Sagoff, We Have Met the Enemy and He Is Us, or Conflict and Contradiction in Environmental Law, 12 Envir.. LAW. 285, 286-87 \& nn. 11-12 (1982).

74. There is a growing literature on the effects of context on preference and the implications these effects have for the legitimacy of collective choice. See generally Sunstein, Legal Interference with Private Preferences, 53 U. CHI. L. Rkv. 729 (1986). For example, people sometimes adapt to their inability to obtain a good by no longer desiring it. See J. EISIER, Sour Graprs (1983). Conversely, it has been shown that people sometimes perceive themselves as more seriously injured when they are
} 
institution of written constitutions would be baffling. Constitutions make sense only if one assumes that what people prefer when they are thinking about problems abstractly will differ from what they prefer at a later time when the problem is real and immediate, and that they have a secondorder preference for an abstract context. ${ }^{75}$

It is therefore pointless to demand that people be consistent. We simply want different things at different times and in different contexts. Most people value both universal beneficence and particular caring, and a person who is not caught between the irreducibly conflicting demands of these requirements strikes most of us as incomplete in a fundamental way. To give up entirely on either universalist principle or particularist choice is to give up on crucial values.

\section{Interventionism Versus Libertarianism}

The implications these observations hold for the institutional arrangements we should favor are far from clear. One possible view is that families and legislatures, like the individuals who are part of them, should be in perpetual internal conflict between private and public values. Advocates of this view argue that it is misleading to suppose that institutions could ever provide a refuge from the conflict we must always feel between our public and private selves. Segmenting people's lives into various conflicting roles to be played in different contexts is constricting and unrealistic. ${ }^{76}$ Instead of artificially dividing our lives in contradictory ways depending

deprived of something they already have than when they are not given something they want. See, e.g., Kelman, Consumption Theory, Production Theory, and Ideology in the Coase Theorem, 52 S. CAL. L. REv. 669 (1979). Still other preferences may be a function of the very government policies that they supposedly justify. See infra text accompanying notes 134-37. On whether second order preferences can exist, see J. Eisirir, UI.yssrs and THE Sirkns (1979) [hereinafter Ulysses]; Jeffrey, Preference Among Preferences, 71 J. PHIL. 377 (1974); Schelling, The Intimate Contest for SelfCommand, 60 PuB. INIFRksi 94 (1980).

75. See, e.g., Ut.yssfs, supra note 74, at 37. It nonetheless remains unclear why the second-order preference should be privileged. Since this preference must itself be expressed in either an abstract or immediate context, it may well be infected by the very contextuality it attempts to transcend. See infra text accompanying notes 189-90.

76. Marx, for example, appears to have held this view. He thought that mere political emancipation forced individuals into a

double life, a heavenly and an earthly life, a life in the political community, wherein he counts as a member of the community, and a life in bourgeois society, wherein he is active as a private person, regarding other men as a means, degrading himself into a means and becoming a plaything of alien powers.

K. MARX, On the Jewish Question, in Ski.kcrrvo Essays 55-56 (H. Stenning trans. 1926). Authentic human emancipation could only be achieved when

individual man is identical with the citizen, and has become a generic being in his empirical life, in his individual work, in his individual relationships, [when] man has recognized and organized his own capacities as social capacities, and consequently the social force is no longer divided by the political power....

Id. at 84-85. 
on the context in which we act, we need to integrate them by bringing to bear our conflicting intuitions on every decision we make. ${ }^{77}$

There is surely some force to this position. It may be true, for example, that our public and private decisions need to be informed by insights derived when we act in the opposite sphere. Opponents of school segregation and euthanasia may not be able to advance their public positions with quite the same fervor if they remain in touch with their private personalities. Perhaps it is also possible and desirable to lead a fully integrated life while simultaneously entertaining contradictory views about the world. If so, then I cannot see an argument for constitutional arrangements, enforced by judicial review, designed to maintain separate public and private spheres.

It seems to me at least plausible, however, that this sort of complete integration is neither possible nor desirable-or, in any event, that even if it were possible and desirable in theory, it would be extremely difficult for many people in our culture to achieve it in practice. ${ }^{78} \mathrm{~A}$ whole person needs to develop both the universalist and particularist sides of her personality and needs to understand that these impulses contradict each other. But at any particular moment a person must stand somewhere. She cannot simultaneously be both for and against school segregation.

As the euthanasia and segregation examples suggest, people in our culture often attempt to soften this contradiction by operating in different contexts within which particularist and universalist impulses can be nurtured. ${ }^{79}$ Of course, even if people do require separate spheres to play out the particularist and universalist aspects of their personalities, it does not

77. Passages in the work of Roberto Unger suggest that he holds this view. Unger rejects the idea that the contradictions between the particular and universal which are central to liberal thought can be denied or overcome. "[T]he outright denial of the differences that liberalism turns into oppositions would fail to account for some crucial aspect of our experience of what the world is like, or of our intentions as moral beings." R. UN(ikR, KNOwL.EDGE AND Pol.rTICs 139 (1975). Even in a community "held together by an allegiance to common purposes," this conflict cannot be transcended. Id. at 220. "The experiences of immanent order and of transcendence can never be wholly reconciled as long as man retains the gift of consciousness. No one can ever love everyone else as concrete individuals; nor can he lose all sense of his isolation from them without sacrificing individual identity." Id. at 260. But although this ideal is not achievable, it does not follow for Unger that it is right to avoid approaching the ideal by taking refuge in separate roles or spheres. Thus, his theory of community

tries . . . to determine what sympathetic social relations would look like and thus to describe the political equivalent of love. Two factors coalesce in sympathy: the communion of purposes by virtue of which each views the other as a complementary rather than as an antagonistic will, and the willingness to see and treat others as concrete individuals rather than as role occupants.

Id. at 261; see also Tushnet, Following the Rules Laid Down: A Critique of Interpretivism and Neutral Principles, 96 HARv. L. Rkv. 781, 825-27 (1983) (communities of understanding "painstakingly created by people who enter into certain kinds of relations and share certain kinds of experiences").

78. Unger posits political arrangements radically different from those existing today as a prerequisite to the creation of "sympathetic" social relations. R. UNGER, supra note 77, at 252, 262-67.

79. See supra text accompanying notes 73-75. 
automatically follow that these spheres should correspond to the dividing line between government and nongovernment institutions. In particular, there is nothing wrong with an individual, or with nongovernment institutions, that are sometimes influenced by universalist impulses. Moreover, it is almost certainly simplistic to suppose that the conflict between universalism and particularism can be captured by a dichotomous division. We operate in a range of contexts within which ever widening groupings claim our attention-from self, to family, to community and nation, to species and beyond.

Although it is wrong to assume that personal, private decisions are necessarily particularist, there is an association between representative government and universalism. For example, there is a close link between the utilitarian insistence on equally weighing of utilities and political theories that require government institutions to equally aggregate preferences. True, even a government that exhibits equal concern and respect for all its citizens is to some degree particularist. No matter how inclusively we define the community, the line must always be drawn somewhere. Thus, our current government does not exhibit the same concern for Mexicans that it does for its own citizens-and, even if it did, the problems posed by the welfare of future generations, of animals, and ultimately, I suppose, of plants and rocks would loom.

No government can be perfectly universalist, but the ideal of public citizenship, of political office open to all, and of public institutions equally responsive to the welfare of each member of the community, pushes us toward the universalist end of the continuum. As civic virtue theorists have persuasively argued, government institutions provide a context for people to view problems from a broader "public interest" rather than a narrower selfish or chauvinistic perspective. ${ }^{80}$ If universalist values are attractive, then it makes sense for people to precommit themselves, through constitutional provisions, to the preservation of a government sphere that encourages choices based on those values.

Paradoxically, this association between government and universalism also provides a double-barreled argument for nonintervention. One half of the argument has already been advanced by the pluralist and civic virtue models of constitutional review. According to these views, when government decisions are not fully public-either because certain groups are excluded from the political process, or because government institutions have been captured by special interests intent upon effecting a naked wealth

80. See supra notes 32, 63; see also Sax, The Legitimacy of Collective Values: The Case of the Public Lands, 56 U. Colo. L. Rrv. 537 (1985) (decisionmaking apparatus of state is only means for expression of civic values). 
transfer unjustified by public purpose-government intervention is unconstitutional. $^{81}$

Alone, however, pluralist and civic virtue theories fail to explain why there should be constitutional limits on intervention by a fully public government or why, indeed, the Constitution should not be read to mandate such intervention. The second half of the argument, which these theories overlook, is premised on the desirability of maintaining particularist values. Precisely because government intervention must keep a universalist orientation, some limit on that intervention is necessary. The point is not that individuals operating in the private sphere necessarily will, or should, be uninfluenced by universalist concerns. It is, rather, that pervasive, universalist government intervention would allow no space for particularist choice. Thus, the ideal of a "public" government necessarily entails its opposite: a "private" sphere, protected from public intervention, within which people are free to form individualized relationships that cannot be justified under the requirements of impersonal beneficence.

\section{Openness Versus Privacy}

For post-Lochner generations skeptical of "natural" limits on government intervention, the concept of separate government and nongovernment spheres is profoundly problematic. As argued above, ${ }^{82}$ the government's toleration of a non-government sphere is, itself, government action with predictible consequences for which the government is responsible. There is, therefore, a serious risk of self-contradiction: If all government decisions must be justified under universalist criteria, then the government's toleration of a particularist sphere must be defended on universalist terms. But this insistence that particularist decisions be justified under universalist criteria negates their particularist character, which destroys the very values we purport to preserve.

To avoid this self-contradiction, libertarian theories must reestablish the distinction between "action" attributable to the government, which must therefore be judged by universalist norms, and "inaction" leaving untouched private decisions for which the government bears no responsibility, and which may therefore be based upon particularist norms. In a post-Lochner world without natural boundaries, this distinction can only be maintained by a precommitment that defines the contexts in which government "action" and "inaction" occur.

In his work on precommitment and imperfect rationality, ${ }^{83}$ Jon Elster

81. See supra notes 31-32.

82. See supra text accompanying notes 58-61.

83. Ul.ysSEs, supra note 74. 
suggests some forms this precommitment might take. Elster explores Pascal's famous "wager argument" for belief in God: ${ }^{\mathbf{8 4}}$ If there is some possibility that God exists and if a person believing in God receives a large payoff if he is right, then a person intent on maximizing utility would so believe. As Pascal understood, however, the efficacy of a belief can never by itself provide reasons for adopting that belief. A person wishing to pursue this strategy must therefore precommit to undertaking a course of action whereby she will come to have utility maximizing beliefs for nonutility maximizing reasons. Since she cannot both believe that something is true, and also believe that that belief stems solely from a decision to believe that it is true whether or not it actually is, a successful precommitment strategy requires binding herself in a manner that induces forgetfulness about the source of the belief.

Something like this strategy is at work in the maintenance of separate government and nongovernmental spheres. By manipulating the amount of information available-by creating in advance the correct mix of openness and secrecy-we can both precommit to separate particularist and universalist decision criteria and hide the particularist or universalist motive for the precommitment.

It is thus no coincidence that a variety of legal doctrines associate secrecy and exclusivity with a particularist, nongovernmental sphere or that the word "privacy" has a double connotation, suggesting both the absence of information and the absence of government. The Court has gone to extraordinary lengths to protect particularist, nongovernmental decisions from the glare of publicity. The right of a woman to secrecy in electing between childbirth and abortion, ${ }^{80}$ the whole structure of Fourth Amendment law protecting home and family from public intrusion, ${ }^{86}$ and our

84. The discussion that follows is drawn from id. at 47-57.

85. In Thornburgh v. American College of Obstetricians \& Gynecologists, 106 S. Ct. 2169 (1986), for example, the Court explicitly linked government nonintervention designed to assure vindication of particularist values in the abortion decision to secrecy designed to shield that decision from universalist criticism. Thus, a woman's decision whether to have an abortion is immune from government interference because:

Our cases long have recognized that the Constitution embodies a promise that a certain private sphere of individual liberty will be kept largely beyond the reach of government. That promise extends to women as well as to men. Few decisions are more personal and intimate, more properly private, or more basic to individual dignity and autonomy, than a woman's decision ... whether to end her pregnancy.

Id. at 2184-85 (citations omitted). Having established the particularist nature of the decision, the Court found that a precommitment to secrecy was necessary to shield this decision from universalist criticism:

The decision to terminate a pregnancy is an intensely private one that must be protected in a way that assures anonymity....

$\Lambda$ woman and her physician will necessarily be more reluctant to choose an abortion if there exists a possibility that her decision and her identity will become known publicly. Id. at 2181-82.

86. See, e.g., Bowers v. Hardwick, 106 S. Ct. 2841 (1986) (Blackmun, J., dissenting): 
insistence on making a range of "tragic choices"-which are almost always particularist in character-through low-visibility mechanisms that maximize discretion and minimize the application of general standards ${ }^{\mathbf{8 7}}$ provide but a few examples. ${ }^{88}$ Through a precommitment to a kind of ignorance, universalist institutions are able to wall themselves off from the consequences of inaction, thereby preserving a particularist sphere without having to offer a universalist justification for particularism.

Conversely, when a nongovernment actor publicizes a particularist decision, we are no longer able to "forget" the consequences of government inaction, and the actor therefore may be taken to have submitted herself to universalist jurisdiction. Thus, businesses that open themselves to the public are sometimes treated as government entities subject to universalist constraints for constitutional purposes, ${ }^{89}$ and individuals who act in public

The [homosexual sodomy] for which Hardwick faces prosecution occurred in his own home, a place to which the Fourth Amendment attaches special significance.

Id. at 2852.

Statutes banning public sexual activity are entirely consistent with protecting the individual's liberty interest in decisions concerning sexual relations: the same recognition that those decisions are intensely private which justifies protecting them from governmental interference can justify protecting individuals from unwilling exposure to the sexual activities of others. But the mere fact that intimate behavior may be punished when it takes place in public cannot dictate how States can regulate intimate behavior that occurs in intimate places.

Id. at 2855.

87. Professors Calabresi and Bobbitt have noted the tendency of our society to relegate "tragic choices" to juries or "aresponsible" agencies that are decentralized, exercise wide discretion, make no precedent, and follow few rules. G. CaI.ABresi \& P. Bobbrtr, Tragic: Choices 57-72 (1978). One characteristic of such decisionmakers is that their procedures tend to shield them from universalist criticism, and it seems plausible that we therefore adopt such procedures in those cases where we value particularist allocations.

88. Ironically, secrecy also may be required to maintain the nongovernmental status of groups that contribute to the universalist quality of government institutions. In Roberts v. United States Jaycees, 468 U.S. 609 (1984), for example, the Court identified two distinct lines of authority protecting the right of association. One group of cases, granting to "highly personal relationships a substantial measure of sanctuary from unjustified interference by the State," $i d$. at 618, is preoccupied with the protection of particularist values. But a second group of cases cannot be explained on this rationale. The Court has "long understood as implicit in the right to engage in activities protected by the First Amendment a corresponding right to associate with others in pursuit of a wide variety of political, social, economic, educational, religious, and cultural ends." Id. at 622 . Here, government intervention threatens not the particularist nature of the private sphere, but the universalist nature of the government sphere. If such nongovernmental political organizations were not shielded from government control, the current balance of forces within government would simply replicate itself within the groups trying to influence government, thereby freezing the status quo and preventing government from being fully representative. Consequently, it is necessary to create space between state and politics. See Cover, supra note 31, at 1311. Not surprisingly, one means of maintaining this space is a precommitment to a measure of secrecy regarding nongovernmental political organizations. See, e.g., Brown v. Socialist Workers '74 Campaign Comm., 459 U.S. 87 (1982) (state cannot constitutionally compel Socialist Workers Party to report names of contributors and campaign workers); NAACP v. Alabama ex rel. Patterson, 357 U.S. 449 (1958) (court may not require NAACP to provide membership list).

89. See, e.g., Evans v. Newton, 382 U.S. 296, 299 (1966); Bell v. Maryland, 378 U.S. 226, 314 (1964) (Goldberg, J., concurring) (private property used in a manner of public consequence implicates public interest); Marsh v. Alabama, 326 U.S. 501, 506 (1946) (public use of property requires limiting owner's rights so as to protect rights of users). On other occasions, the Court has treated the 
ways are said to "waive" their Fourth Amendment rights and "reasonable expectation of privacy."

Just as a precommitment to secrecy protects particularism, so a precommitment to publicity protects universalism. A highly visible decisionmaking process is more likely to be criticized by all affected groups than a less visible process. The more visible decisionmaker is accordingly more likely to consider these criticisms. Visibility also promotes a public dialogue in which people think as public citizens and so transcend, to some extent, particularist concerns. Theories of the First Amendment that emphasize the "checking" function of the press, ${ }^{91}$ as well as "structural due process" theories that require legislatures to consider various options and candidly commit themselves to the reasons for their decisions, ${ }^{92}$ are based on some such notion.

In summary, the universalist dilemma, the interventionist dilemma, and the openness dilemma are interconnected. If we are to have a universalist government that accords all members of the community equal concern and respect, then limits must be placed on interventionism in order to allow space for particularist decisions. And if we are to avoid the contradiction inherent in providing universalist justifications for particularist decisions, then we must pre-establish mechanisms assuring secrecy for particularist decisions, so that the government can "forget" the particularist consequences of its inaction.

\section{Interventionism, Skepticism, and the Problem of Judicial REVIEW}

The theory set out above implies the need for a constitutional guarantee of separate public and private spheres. By itself, however, it provides no basis for insisting on the special competence of judges to articulate constitutional values. Historically, many efforts to justify such a role for judges have foundered on the difficulty of providing a principled defense for any

absence of exclusivity as a justification for legislative universalist intervention. See, e.g., Roberts v. United States Jaycees, 468 U.S. 609, 621-22 (1984); Tillman v. Wheaton-Haven Recreational Ass'n, 410 U.S. 431, 438-39 (1973) (non-exclusive operation of community swimming pool violates antidiscrimination statute by excluding blacks).

90. See supra text accompanying notes 47-50.

91. See, e.g., Richmond Newspapers v. Virginia, 448 U.S. 555 (1980). The Court held: "[T]hroughout its evolution, the trial has been open to all who cared to observe." Id. at 564. "[Openness provided] assurance that the proceedings were conducted fairly to all concerned, and it discouraged perjury, the misconduct of participants, and decisions based on secret bias or partiality." Id. at 569. "In guaranteeing freedoms such as those of speech and press, the First Amendment can be read as protecting the right of everyone to attend trials so as to give meaning to those explicit guarantees." Id. at 575.

92. See, e.g., Schweiker v. Wilson, 450 U.S. 221, 244-45 (1981) (Powell, J., dissenting) (Court should be skeptical of legislative justifications created after the fact); Fullilove v. Klutznick, 448 U.S. 448, 553 (1980) (Stevens, J., dissenting) (Congress should state reasons for class-based statutes). 
particular boundary between public and private. ${ }^{93}$ In this Section, I suggest some reasons why conventional efforts to deal with this problem seem so unsatisfying. The next Section offers an alternative approach that sidesteps the problem of principle.

\section{A. Justice Holmes and the Source of the Difficulty}

One can trace the intellectual origins of contemporary confusion concerning judicial review to two brief dissenting opinions written by Justice Holmes when the schism in classical liberalism was first becoming apparent. In Lochner v. New York, ${ }^{94}$ Holmes objected to the Court's use of substantive due process to invalidate New York's maximum hours legislation for bakers. Fourteen years later, in Abrams v. United States, ${ }^{95}$ he opposed the Court's refusal to recognize the First Amendment rights of two defendants who had published leaflets attacking American participation in the Russian civil war.

In some important respects the two dissents share common premises that have been seminal in the development of modern constitutional law. These premises, in turn, stem from strands in utilitarian theory that substantially influenced Holmes' thought. ${ }^{96}$ Both opinions, for example, manifest a profound distrust of deductive reasoning ${ }^{97}$ and a skepticism about whether one can ever justify decisions regarding ends and values. ${ }^{98}$ In Lochner, he warned that "[g]eneral propositions do not decide concrete cases," intuition more subtle than any articulate major premise."100 $\mathrm{He}$ was, therefore, unwilling to allow the case to turn on his view of the correct-

93. See supra text accompanying notes 58-65.

94. 198 U.S. 45 (1905).

95. 250 U.S. $616(1919)$.

96. See generally H. Pohlman, Jusitce: Ot.tver Wendil. Holmes and Utiltrarian JurisPRUDENCE: (1984) (discussing utilitarian influences on Holmes).

97. For an attempt to trace the utilitarian roots of this distrust of syllogistic reasoning to the works of Jeremy Bentham, John Stuart-Mill, and John Austin, see id. at 106-26. Austin was especially insistent that judges reason from analogy rather than through a syllogistic process. See, e.g., J. AUstin, 2 LrCiURES ON JURISPRUDENCE: 1036-55 (1873).

98. The distinguishing feature of utilitarian morality, in all its various permutations, is its consequentialist base which depends, in turn, on agnosticism about the appropriate sources of the utility to be maximized. See, e.g., Williams, A Critique of Utilitarianism, in J. SMART \& B. WILLIAMS, UtruTARIANISM: FOR AND A(;AINST 79-80, 82-85 (1973). For Holmes, this agnosticism ran very deeply. He wrote that:

[d] eep-seated preferences can not be argued about-you can not argue a man into liking a glass of beer-and therefore, when differences are sufficiently far reaching, we try to kill the other man rather than let him have his way. But that is perfectly consistent with admitting that, so far as appears, his grounds are just as good as ours.

O. Holmes, Col.t.cintid Ligal. Papers 312 (1921). See generally H. Pohlman, supra note 96, at 11-47 (discussing Holmes' agnosticism concerning values).

99. 198 U.S. at 76 (Holmes, J., dissenting).

100. Id. 
ness of the policy behind the New York statute; were the correctness of that policy at issue, he "should desire to study it further and long before making up my mind."101 In Abrams, Holmes was willing to venture the opinion that the defendants' creed was one of 'ignorance and immaturity when honestly held."102 But his argument for constitutional protection rested crucially on his inability to be certain of the correctness of this judgment. Thus, he acknowledged that "[i]f you have no doubt of your premises . . . and want a certain result with all your heart, ${ }^{, 103}$ protection for opposing ideas would make little sense. Freedom of speech has value only because "men have realized that time has upset many fighting faiths."104 Ironically, Holmes insisted on skepticism even with regard to his own skeptical theory. The most he would say was that it "is an experiment, as all life is an experiment. Every year if not every day we have to wager our salvation upon some prophecy based upon imperfect knowledge."105

Closely allied to this skepticism was Holmes' belief that the Constitution required government neutrality with respect to competing individual conceptions of the good. Because such conceptions cannot be derived from deductive logic, and because no one can be certain which conception is correct, advocates of any particular conception should not be permitted to capture our collective institutions. ${ }^{106}$ Instead, government has an obligation to accord equal weight to the desires of each of its citizens. Thus, for Holmes, the Lochner majority was wrong to frustrate the will of the New York legislature because it was insisting on "an economic theory which a large part of the country does not entertain."107 The Constitution was "not intended to embody a particular economic theory, whether of paternalism and the organic relation of the citizen to the State or of laissez faire. It is made for people of fundamentally differing views . . .."108 Similarly in Abrams, Holmes was unwilling to entertain the notion that the defendants could be punished because they had a deviant conception of the good. However silly or pernicious their beliefs seemed, "no one has a right even to consider [the creed that they avow] in dealing with the charges before the Court."108

These central premises of the Lochner and Abrams dissents-an insis-

101. Id. at 75 .

102. 250 U.S. at 629 (Holmes, J., dissenting).

103. Id. at 630.

104. Id.

105. Id.

106. The requirement of government neutrality, in this sense, is a central tenet of modern liberalism. See, e.g., B. $\Lambda$ ckeRMAN, supra note 15, at 10-15.

107. 198 U.S. at 75 (Holmes, J., dissenting).

108. Id. at $75-76$.

109. 250 U.S. at 630 (Holmes, J., dissenting). 
tence on value and rule skepticism, on government neutrality, and on the equal status of competing conceptions of the good-have been profoundly influential in the development of liberal constitutional theory. But there is also a tension between Holmes' position in Abrams and his position in Lochner-a tension that, in the long run, has turned out to be even more significant than the shared premises. Although both opinions are heavily influenced by value and rule skepticism, that skepticism leads Holmes to opposite conclusions in the two cases. In Lochner Holmes argues that value skepticism required deference to the legislature, yet in Abrams the same skepticism required judicial invalidation of the statute, at least as applied. In Lochner, Holmes refused to saddle the country with the view that laissez faire economics necessarily produces a just and efficient distribution of goods. In Abrams, he insisted that the First Amendment establishes a free marketplace of ideas ${ }^{110}$ that will necessarily yield the truth. In Lochner, he was willing to permit the legislature to proceed on the theory that private markets were not necessarily free, and that government intervention might be necessary to offset inequalities in bargaining power. Yet his Abrams opinion seems to rest on the belief that speech is automatically "free" when the government does not restrict it and that conflicting ideas will compete on an equal basis as long as the government does not intervene.

Holmes' ambivalent attitude toward government power is symptomatic of deeper difficulties with utilitarian thought. On the one hand, as a political theory, utilitarianism seems to argue for deference to the legislative branch: Whatever its deficiencies, the legislature is the public institution that most fairly aggregates individual preferences. Moreover, any effort by judges to use legal reasoning from natural law principles or the constitutional text to control the legislature's product would necessarily resort to "general propositions" that "do not decide concrete cases."111

On the other hand, as a moral theory, utilitarianism demands that individual conduct be guided by principles of universal utility maximization. If one grants broad deference to legislative decisions, one must accept the risk that some of those decisions may arise from preferences that cannot be justified under a system of utilitarian morality. For example, the legislature might outlaw expression of deviant political views because a majority rejects the right of a minority to pursue certain conceptions of the good. Thus, if one accepts utilitarian political theory and opts for legislative autonomy, one must be prepared to live with some legislative results that

110. See id.

111. 198 U.S. at 76. On the association between utilitarian morality and representative government, see Hart, Between Utility and Rights, 79 Col.um. L. Rev. 828, 843 (1979). 
could not be justified on utilitarian moral theory ${ }^{\mathbf{1 1 2}}$ Indeed, utilitarian political theory may itself amount to no more than "general propositions" that "do not decide concrete cases." Holmes seems to acknowledge this possibility in Lochner: "The liberty of the citizen to do as he likes so long as he does not interfere with the liberty of others to do the same, which has been a shibboleth for some well-known writers,"113 cannot serve as a test for the constitutionality of legislation.

Deferring to the legislature in this fashion, however, permits the very thing that utilitarian theory says must be resisted-the capture of our public institutions by proponents of some particular conception of the good and the suppression of competing conceptions. Holmes acknowledged in Abrams that his theory is no more than an "experiment,"114 but he was unwilling to allow the theory to consume itself. Therefore,

[w]hile that experiment is part of our system[,] . . . we should be eternally vigilant against attempts to check the expression of opinions that we loathe and believe to be fraught with death, unless they so imminently threaten immediate interference with the lawful and pressing purposes of the law that an immediate check is required to save the country. ${ }^{115}$

\section{B. The Carolene Products Compromise}

So long as the Court remained within the control of natural law theorists of the right, these contradictions in utilitarian thought could be repressed. Justice Holmes and his allies could take as given the "general propositions" that restricted legislative power and argue that, if these propositions were to control at all, they ought to be deployed in a manner

112. As Professor Dworkin has argued, rigid adherence to the requirement that all preferences should be counted equally leads utilitarianism into an internal contradiction:

Suppose, for example, that a number of individuals in the community hold racist rather than utilitarian political theories. They believe, not that each man is to count for one and no one for more than one in the distribution of goods, but rather that a black man is to count for less and a white man therefore to count for more than one. . . . If this preference or pleasure is given the normal weight in a utilitarian calculation, and blacks suffer accordingly, then their own assignment of goods and opportunities will depend, not simply on the competition among personal preferences that abstract statements of utilitarianism suggest, but precisely on the fact that they are thought less worthy of concern and respect than others are.

R. Dworkin, TAking Righrs Seriousi.y 275 (1978); see also Williams, supra note 98, at 135-50. But see Hart, supra note 111 , at 828,843 ("Where those who are denied by a majority vote the liberty they seek are able . . . to continue to press their views in public argument . . . it seems quite impossible to construe every denial of liberty by a majority vote based on external preferences as a judgment that the minority whom it defeats are of inferior worth.").

113. 198 U.S. at 75 (Holmes, J., dissenting).

114. 250 U.S. at 630 (Holmes, J., dissenting).

115. Id. 
that suited their ends. ${ }^{118}$ When the sudden collapse of the old order in the late 1930's, and the ascendancy of the Roosevelt majority, cast doubt on these "general propositions," the need for reconciling the opposing implications of utilitarian theory became more pressing.

Two polar resolutions were possible. On the one hand, the new majority might have taken seriously the claim of value skepticism and opted for legislative supremacy. On the other hand, it might have taken seriously the claim of equality in pursuit of the good and opted for judicial intervention whenever legislative action or inaction threatened such equality. Although elements of the new majority became associated with each of these poles, the dominant force in modern constitutional theory emerged from an effort to forge a compromise between them. That compromise, embodied in the famous Carolene Products footnote, ${ }^{117}$ coupled a limited textualism with a heavily process-oriented form of judicial review.

Where a specific constitutional provision limited the legislature, there was no need for the Court to rely upon its own value judgments to justify intervention. On the contrary, value skepticism argued for rigid judicial adherence to those values specifically articulated in the constitutional text. The Court could therefore block implementation of certain legislative values without having to justify values of its own. ${ }^{118}$

In the absence of specific textual provisions, judicial intervention was more problematic. It could still be justified, however, if the Court refrained from articulating values itself and merely insisted that the legislative process fairly reflect and aggregate competing views. Thus, if the legislature restricted "those political processes which can ordinarily be expected to bring about repeal of undesirable legislation," 119 or acted against "discrete and insular minorities" where "prejudice" tended "seri-

116. See Cover, supra note 31, at 1288 (recognition by Holmes and Brandeis of "a limited role for substantive due process was tactical only and highly contingent").

117. See United States v. Carolene Prods. Co., 304 U.S. 144, 152 n.4 (1938).

118. The first paragraph of the footnote states:

There may be narrower scope for operation of the presumption of constitutionality when legis-

lation appears on its face to be within a specific prohibition of the Constitution, such as those

of the first ten amendments, which are deemed equally specific when held to be embraced within the Fourteenth.

Id. at 152 n.4. Apparently added at the insistence of Chief Justices Hughes, see Lusky, Footnote Redux: A Carolene Products Reminiscence, 82 Colum. L. REv. 1093, 1098 (1982), the paragraph is puzzling in two respects. First, its endorsement of textualism stands in sharp contrast to the functional thrust of the following two paragraphs. See Cover, supra note 31, at 1291 . Second, even on its own terms, the endorsement is contradictory, since the Court provides no textual argument for its support of the incorporation doctrine.

119. 304 U.S. at 152 n.4. The second paragraph of the footnote states:

It is unnecessary to consider now whether legislation which restricts those political processes which can ordinarily be expected to bring about repeal of undesirable legislation, is to be subjected to more exacting judicial scrutiny under the general prohibitions of the Fourteenth Id.

Amendment than are most other types of legislation. 
ously to curtail the operation of those political processes ordinarily to be relied upon to protect minorities," ${ }^{120}$ a court might alter the outcome to yield the result that would have emerged from a properly functioning legislative process.

In the years since Justice Stone first formulated the Carolene Products compromise, it has been subjected to a series of withering critiques. ${ }^{\mathbf{1 2 x}}$ Although its deficiencies are plain enough, there are elements of brilliance in its reconciliation of the competing strands of utilitarian thought. Most obviously, the compromise seemed to reconcile value skepticism with an insistence on utilitarian values. By channelling value inquiry into either noncontroversial textual provisions or process values, the Court hoped to avoid the embarassment of appearing to foist its own values on the rest of the country. Yet the textual and process review, which Carolene Products preserved, seemed to give the Court adequate tools to correct the majority's systematic undervaluation of minority group welfare.

More subtly, there was also reason to hope that Carolene Products would harness judicial review in support of an interventionist political agenda. During the Lochner era, judicial review too often led to the frustration of political initiatives to redistribute power and resources in the private sphere. Many of those supporting Carolene Products were sympathetic to such initiatives. The Carolene Products compromise promised to legitimate and support such intervention. By insuring that the political branches fairly represented everyone and remained open to political check, the Court could neutralize a potent argument against government interference with private markets. Paradoxically, by invalidating certain kinds of legislation, the Court was able to provide a necessary predicate for more general legislative dominance over the private sphere. Carolene Products thus promised to turn the traditional role of judicial review on its head.

Yet for all its brilliance, the Carolene Products compromise ultimately failed. The various weaknesses of the compromise are by now familiar, and there is no need to rehearse them in detail. For present purposes, the most significant problems stem from its failure to tame the very value-

\footnotetext{
120. The footnote's concluding paragraph states:

Nor need we enquire whether similar considerations enter into the review of statutes directed at particular religious, ... or national, ... or racial minorities, ... whether prejudice against discrete and insular minorities may be a special condition, which tends seriously to curtail the operation of those political processes ordinarily to be relied upon to protect minorities, and which may call for a correspondingly more searching judicial inquiry. 304 U.S. at 153 n.4.

121. See, e.g., Ackerman, supra note 31; Brest, The Substance of Process, 42 OHIO ST. L.J. 131 (1981); Parker, The Past of Constitutional Theory-And Its Future, 42 OHo ST. L.J. 223 (1981); Tribe, The Puzzling Persistence of Process-Based Constitutional Theories, 89 YALE L.J. 1063, 1072-77 (1980). For some judicial critiques, see Sugarman v. Dougall, 413 U.S. 634, 656-57 (1973) (Rehnquist, J., dissenting); Kovacs v. Cooper, 336 U.S. 77, 90-91 (1949) (Frankfurter, J., concurring); Powell, Carolene Products Revisited, 82 Colum. L. Rev. 1087 (1982).
} 
skepticism that necessitated the compromise in the first place. Without effective control, the corrosive force of this skepticism could be turned on the compromise itself. Thus, textualism, even in its most sophisticated incarnations, does not confine judicial discretion sufficiently to legitimate judicial power. ${ }^{122}$ Moreover, the process values upon which Carolene Products relied proved to be neither uncontroversial nor capable of disentanglement from substantive decisions. For example, repeated incantations of the "one person, one vote" slogan failed to hide the fact that there are different ways to aggregate individual votes and that these different methods, none of which is obviously "unfair," yield radically different outcomes. ${ }^{128}$ Similarly, the compromise provided no obvious method for distinguishing between groups that failed politically because of systematic "prejudice" and groups that were simply outvoted-between homosexuals and exhibitionists, in Professor Tribe's telling example. ${ }^{124}$

Characterizing Carolene Products as resting on controversial value determinations allowed the contradictions in the utilitarian position to reemerge. Indeed, the characterization revealed that the compromise itself rested on a contradiction. Advocates of Carolene Products never adequately explained how equal representation was advanced by vesting power in our least representative institution. Granted, legislative bodies function imperfectly and not all groups are adequately represented, but no institutional arrangements function perfectly. The relevant question should be comparative rather than absolute: Is vesting power in one institution "better" than vesting it in another?125 When viewed from this perspective, it is difficult to refute those who argue that the choice between competing theories of public representation is itself a public question, best resolved by the institution most responsive to the public will. ${ }^{126}$

122. On the problems with textualism, see generally Dworkin, The Forum of Principle, 56 N.Y.U. L. REv. 469 (1981); Powell, The Original Understanding of Original Intent, 98 HaRv. L. REV. 885 (1985); Tushnet, supra note 77, at 784-802.

123. See, e.g., Neal, Baker v. Carr: Politics in Search of Law, 1962 Sur. CT. Rev. 252, 275-84.

124. Tribe, supra note 121, at 1075-76; see also Ackerman, supra note 31, at 731-37 (describing the empirical factors that might inform claims of prejudice).

125. See generally Komesar, Taking Institutions Seriously: Introduction to a Strategy for Constitutional Analysis, 51 U. CHI. L. REv. 366 (1984).

126. Dean Ely has argued that elected representatives are subject to an inherent conflict of interest in assessing whether the process by which voters choose them is fairly representative. As "comparative outsiders in our governmental system," appointed judges are better able "objectively to assess claims . . . that either by clogging the channels of change or by acting as accessories to majority tyranny, our elected representatives in fact are not representing the interests of those whom the system presupposes they are." J. ELY, supra note 27, at 103. But as Professor Komesar has demonstrated, this argument rests on a non sequitur. Legislators may indeed be subject to a conflict of interest when they investigate the limits of their own power. But it does not follow that judges are "comparative outsiders" less subject to the temptations of biased self-aggrandizement. When a court asserts the power to invalidate a statute, it not only curbs legislative power, but also enhances its own power. There is therefore no neutral solution to the problem of tyranny. The appropriate question to ask is not whether the legislature is perfectly responsive to the popular will, but whether, conceding all the 
Ironically, this failure to legitimate judicial intervention also frustrated the hope of Carolene Products' supporters that the compromise would help guarantee governmental supremacy over the private sphere and thereby further the interventionist political agenda. The interventionist theory of autonomy required confident assertions of government power to control the private forces limiting real freedom. In theory, the Carolene Products compromise might have provided a basis for enlisting the courts in this endeavor. When the political branches failed to intervene to advance the causes of powerless minorities, the Court might have required the government programs that would have been adopted if these minorities had been fairly represented.

Although the Court has occasionally flirted with the interventionist version of Carolene Products, ${ }^{127}$ the activist potential of the compromise has rarely been realized. The reasons for this failure almost surely relate to the indeterminate character of the compromise. Even if the Court could formulate clear standards of "fair" representation, the effort to construct a hypothetical political process and predict its various trade-offs would be staggeringly complex. ${ }^{128}$ In the absence of such standards, action-forcing judicial intervention would be perceived as the kind of judicial interference with the legislative process that the compromise was designed to avoid.

Some cases concerning the problem of gender discrimination illustrate the nature and depth of these difficulties. In Personnel Administrator $v$. Feeney, ${ }^{129}$ the Court considered the constitutionality of a Massachusetts veterans' preference statute that required the state to fill all civil service positions with qualifying veterans before hiring any qualified nonveteran. Although the preference overwhelmingly favored males, the Court held that it did not constitute gender discrimination and, therefore, did not apply heightened review. Writing for the majority, Justice Stewart conceded that "[i]t would . . . be disingenuous to say that the adverse consequences of this legislation for women were unintended, in the sense that they were not volitional or in the sense that they were not foreseeable." ${ }^{\text {130 }}$ Nonethe-

problems with representation, it is likely to be more responsive than the available alternative. See Komesar, supra note 125, at 400-05.

127. See supra note 17.

128. Even in its negative version, the theory rests on significant oversimplifications. As Professor Ackerman has demonstrated, it simply does not follow from the "political powerlessness" of a group that the group would have prevailed if it were unhampered by an inability to form coalitions. Ackerman, supra note 31, at 720-22. Moreover, a group's "discreteness" and "insularity" may actually serve to enhance, rather than diminish, its political power by reducing the "free rider" problems associated with organizing political activity, lessening organizational costs, and eliminating the "exit" option. See id. at 722-31.

129. 442 U.S. 256 (1979).

130. Id. at 278 . 
less, he argued, the preference was not infected by a discriminatory purpose because

"[d]iscriminatory purpose" . . . implies that the decisionmaker . . . selected or reaffirmed a particular course of action at least in part "because of," not merely "in spite of," its adverse effects upon an identifiable group. Yet nothing in the record demonstrates that this preference for veterans was originally devised or subsequently reenacted because it would accomplish the collateral goal of keeping women in a stereotypic and predefined place in the Massachusetts Givil Service. ${ }^{131}$

For anyone committed to the action-forcing implications of the Carolene Products compromise, this limited definition of discriminatory purpose must appear indefensible. Of course, Carolene Products requires heightened scrutiny when the majority passes legislation motivated by the sadistic urge to reduce the welfare of an underrepresented minority group. But it is the rare case indeed in which the legislature harms a minority "because of" rather than "in spite of" this effect. More frequently, lack of adequate representation will cause the legislature to fail to pursue policies benefitting the minority, or to undervalue the minority's welfare when it pursues policies benefitting the majority. There is no reason in principle why Carolene Products should not require restructuring political outcomes when lack of representation leads to this kind of discrimination. Thus, the appropriate question is not whether the Massachusetts legislature enacted the veterans' preference in order to harm women, but whether it would have enacted the same preference if the disadvantaged group had been men. ${ }^{132}$

When one begins to pursue the implications of this question, however, difficulties immediately appear. Even if the counterfactual is restricted to the transposition of men and women, it is hard to see how a court can do more than speculate on the likely political outcome. More significantly, the counterfactual cannot be so restricted. A world in which women, rather than men, would benefit from a veterans' preference would be a very different-indeed, virtually unrecognizable-place. The socialization, perceptions, and desires of men and women would be profoundly altered, and these changes would, in turn, alter public policy in wholly unpredictable ways. ${ }^{133}$

131. Id. at 279.

132. Cf. Brest, The Supreme Court, 1975 Term-Foreword: In Defense of the Antidiscrimination Principle, 90 HaRv. L. Rev. 1, 6-8 (1976) (antidiscrimination principle protects minorities when ostensibly valid reasons for discriminatory rule hide (possibly unconscious) improper motive).

133. The problems run still deeper. In a culture in which socialization differed so radically, women might not perceive themselves as a cohesive group and, therefore, might not perceive their 
These difficulties are further compounded when one begins to consider the effects of restructuring on the goals of the legislature. Both the Feeney majority and dissent assume a basic methodology according to which the constitutionality of a veterans' preference is determined by investigating with varying degrees of rigor the nexus between the means (the preference) and the supposed end (rewarding veterans for service to their country). But it is surely simplistic to treat the end as necessarily unconnected to the discrimination under attack. It is possible, for example, that in a world in which men did not dominate women, the legislature would be interested in rewarding people who made peace rather than war.

The manner in which power is currently distributed between men and women has the potential to affect not only which ends the legislature pursues, but also the behavior of men and women with respect to those ends. Consider, for example, the problem posed by Craig v. Boren, ${ }^{134}$ in which the Court struck down an Oklahoma statute permitting women, but not men, between the ages of 18 and 20 to buy $3.2 \%$ beer. Writing for the majority, Justice Brennan was confronted with a series of empirical studies tending to show that a much higher proportion of men than women in the relevant age group was arrested for driving while drunk. Although Justice Brennan attempts to discredit the empirical evidence, this portion of his opinion is strikingly unpersuasive. ${ }^{135}$ Conceding as much, he concludes by dismissing this entire line of analysis with the observation that "proving broad sociological propositions by statistics is a dubious business, and one that inevitably is in tension with the normative philosophy that underlies the Equal Protection Clause."136

Justice Brennan does not specify the source of this tension, but he may

exclusion as discrimination. See J. Fishkin, Justice, Equal. Opportunity, and The Family 117 (1983) (blacks might not perceive themselves as cohesive group in absence of discrimination).

134. 429 U.S. 190 (1976).

135. The state relied primarily on statistical evidence purporting to demonstrate that $2 \%$ of the males, but only $0.18 \%$ of the females, in the relevant age group were arrested for alcohol-related driving offenses. See id. at 201. Superficially, it might seem that the fact that better than ten times more men than women were arrested for drunken driving would constitute fairly persuasive evidence for a gender-based distinction. But instead of focusing on the disparity between the male and female arrest rates, Justice Brennan attempted to dissipate the impact of the evidence by focusing on the low overall arrest rate for men. Id. at 200-02. The attempt is unpersuasive for a number of reasons. First, as Justice Rehnquist argues in his dissent, the low overall arrest rate seems more relevant to a substantive due process attack on any ban on alcohol consumption than to an equal protection attack on the differential treatment of men and women. See id. at 225-26 (Rehnquist, J., dissenting). Moreover, it is far from clear that the arrest rate is too low to justify the ban. Two percent of the relevant male population, although only a small fraction of the total, may nonetheless be a very large absolute number capable of inflicting tremendous social costs. The actual number of males in the relevant age group who drink and drive is likely to be still larger, since the study recorded only those unlucky enough to be arrested for alcohol-related offenses. Finally, it is important to understand that $2 \%$ of young men were caught drinking and driving despite the existence of laws prohibiting this conduct. But surely widespread obedience to a law does not demonstrate that the law is unconstitutional.

136. Id. at 204. 
well be concerned about the need to break the mutually reenforcing nexus between culture and behavior. It may be true, for example, that in our culture men are more likely than women to drink and drive-perhaps because the ability to "hold" alcohol is somehow associated with masculinity or because men are expected to drive when men and women are in a car together. But this behavior cannot be taken as a given, uninfluenced by the complex socialization of men and women in our society. One significant component of that socialization is the content of messages sent by government actions, such as those under attack in the very case to be decided. In a world where men and women are sent different messages about how they should behave, they might well behave differently. Thus, if the statute is judged solely in terms of whether it tracks existing behavior, there is an unacceptable risk that it will become self-validating.

It follows that anyone seriously committed to a Carolene Products analysis of gender discrimination should treat neither the goals of the legislature nor the behavior of men and women as exogenous. Rather, one must ask what goals the legislature would pursue and how the behavior of men and women would interact with those goals in a "natural" state where people's conduct and desires would be uninfluenced by existing hierarchies.

There are some famous examples of the Court's efforts to pursue this line of analysis. For example, over a century ago, Justice Bradley was uninfluenced by the "exceptional cases" of women who, in the existing culture, pursued legal careers. ${ }^{137}$ Instead, he was prepared to judge the constitutionality of Illinois' refusal to permit women to practice law by measuring it against "the nature of things," 138 allowing him to identify "the domestic sphere as that which properly belongs to the domain and functions of womanhood."138 Nor is it necessary to rummage through discarded precedents from the last century to see how the Court has administered a "natural law" approach once freed from the constraints of existing behavior and norms. Without any empirical support, modern majorities have held that men "by nature" suffer few consequences from teenage pregnancy ${ }^{140}$ and that it is "natural" for women to be more closely attached to young children than men. ${ }^{141}$

Results such as these ought to give pause to advocates of an interventionist version of Carolene Products. Because no one knows how people

137. Bradwell v. Illinois, 83 U.S. (16 Wall.) 130, 141-42 (1872) (Bradley, J., concurring in judgment).

138. Id. at 142 .

139. Id. at 141 .

140. See Michael M. v. Sonoma County Superior Court, 450 U.S. 464, 475 (1981).

141. See Lehr v. Robertson, 463 U.S. 248 (1983); cf. Parham v. Hughes, 441 U.S. 347 (1979) (easier to identify mother of illegitimate child than father). 
would act apart from their culture, any effort to specify a natural state of affairs quickly degenerates into an effort to implement some normative vision of how people should act. ${ }^{142}$ But at this point, all the old doubts about the ability of judges to defend such a vision-doubts that gave birth to the Carolene Products compromise in the first place-reassert themselves.

These doubts, in turn, have caused the Court to adhere for the most part to a libertarian version of the compromise that gives the Court a much less intrusive role. Consider, for example, the Washington v. Davis ${ }^{143}$ doctrine and the Court's modern state action jurisprudence. ${ }^{144}$ These cases treat Carolene Products as prohibiting, rather than mandating, government intervention. The state of affairs that exists in the absence of government action serves as a benchmark that avoids the necessity for speculation about how things might be in a reconstructed world. Government action departing from the benchmark, by making the status of minorities worse, requires justification. In contrast, when the government fails to act, by leaving exercises of private power that harm minorities undisturbed, it bears no responsibility for the results. ${ }^{145}$

But the most damning criticism of the compromise relates to relevance rather than legitimacy or coherence. The problem is not solely that Carolene Products fails to counteract the centrifugal forces of utilitarian jurisprudence or that it does not legitimate a form of judicial review consistent with the interventionist theory of autonomy. More fundamentally, Carolene Products simply fails to describe what has been going on. Many of the Court's most important constitutional pronouncements in recent years-in particular its decisions concerning reproductive autonomy and family values ${ }^{148}$ - seem to have no relationship to Carolene Products analysis in either its interventionist or libertarian incarnations. While a few defenders of the compromise have disavowed these decisions for precisely this reason, ${ }^{147}$ many others have embraced the new privacy. ${ }^{148}$ But

142. For an especially insightful discussion of this point, see R. WASSERSTrom, Philosophy AND SOCIAL. Issues 34 (1980).

143. 426 U.S. 229 (1976).

144. See, e.g., Rendell-Baker v. Kohn, 457 U.S. 830 (1982); Flagg Bros. v. Brooks, 436 U.S. 149 (1978). For an excellent critique, see Brest, State Action and Liberal Theory: A Casenote on Flagg Brothers v. Brooks, 130 U. PA. L. Rev. 1296 (1982).

145. See supra notes 17-18.

146. See, e.g., Carey v. Population Serv. Int'l, 431 U.S. 678 (1977); Moore v. City of East Cleveland, 431 U.S. 494 (1977); Roe v. Wade, 410 U.S. 113 (1973); Stanley v. Illinois, 405 U.S. 645 (1972).

147. See, e.g., Ely, The Wages of Crying Wolf: A Comment on Roe v. Wade, 82 Yale L.J. 920 (1973).

148. See, e.g., Perry, Abortion, The Public Morals, and the Police Power: The Ethical Function of Substantive Due Process, 23 UCLA L. Rev. 689, 733 (1976); Tribe, The Supreme Court, 1972 Term-Foreword: Toward a Model of Roles in the Due Process of Life and Law, 87 HARv. L. REv. 1, 11-22 (1973). For some efforts to defend some aspects of the new privacy in Carolene Products 
no one has yet articulated a comprehensive theory reconciling judicial protection for a private sphere with the interventionist bias that initially motivated the search for compromise.

\section{Judicial Review as Boundary Maintenance}

\section{A. The Boundary Problem}

If the argument spelled out in Section I is correct, then it is important to establish some boundary between a universalist governmental and nongovernmental institutions where people can make particularist decisions. Yet our experience with Lochner's aftermath detailed in Section II leaves us skeptical of the Court's ability to use the tools of logic and precedent to chart such a boundary.

It is important to understand, however, that a theory premised on the desirability of conflict between universal and particular values need not specify a permanent location for the boundary. On the contrary, unlike competing libertarian views, such a theory denies the possibility that any permanent boundary can ever be drawn. Any effort to establish such a fixed line would involve a grand reconciliation between particularist and universalist impulses. But the theory holds that such a reconciliation would be undesirable: Whole persons must forever be caught between impulses that are inherently and unavoidably contradictory.

Because a final resolution of the public/private distinction is neither possible nor desirable, there is a need for some institution to police an ever-shifting boundary. If it is true, as argued above, that context influences preference, ${ }^{140}$ we cannot expect the political process operating alone to fix a boundary that accurately takes into account the weight of our conflicting universalist and particularist impulses.

There are a number of reasons why the voting and representational process is likely to understate the force of particularist values. One difficulty with this process is apparent from the previous discussion: If, as civic virtue theorists contend, collective decisionmaking mechanisms cause people to think in universalist terms, ${ }^{130}$ then the decisions that people make when they vote, or work for political causes, or participate in public, abstract debate will systematically understate the private preferences they would state in more private contexts.

Moreover, this conclusion would still be valid even if we assumed, con-

terms, see L. Tribr, Consrrrurional. Choices 243 (1985); Karst, Book Review, 89 Harv. L. Rev. 1028, 1036-37 (1976) (reviewing G. Gunther, Cases and Materials on Constitutional. LAW (9th ed. 1975)).

149. See supra text accompanying notes 74-76.

150. See supra text accompanying notes 63-64. 
trary to reality, that individual choices between particularist and universalist values are stable and unitary. This is so because distortions are introduced not only when citizens think about how to vote, but also when they think about whether to vote. Voter apathy is a striking and disturbing feature of American democracy. ${ }^{151}$ One extremely plausible explanation for this apathy is that voting is simply irrational for anyone whose private and public aspects of personality are in reasonable balance. On the one hand, the chance of an individual vote affecting the outcome of even local elections is negligible. On the other, the disruption of one's private life in casting a ballot, while usually not overwhelming, is not trivial. It seems likely that people who choose to make private sacrifices to perform this public duty have either an impoverished private life or an exaggerated sense of public responsibility. It would hardly be surprising if the candidates supported by such an electorate tended to undervalue the private aspects of our personalities.

Finally, and perhaps most significantly, distortion is also built into the representation process. Even if the electorate fairly represented the populace as a whole, it is simplistic to suppose that people elected to public office are precise proxies of those who elect them. ${ }^{152}$ One important way in which they are likely to differ is that public officials have less developed private lives than their constituency. In part, this is true because of selfselection: Public life is likely to attract individuals who care less about private relationships than most of us. Moreover, the dynamic of electoral politics often means that even individuals who have well-developed private lives before they seek public office are forced to sacrifice them when they enter politics. Election to important public office often forces a politician

151. See, e.g., R. Cantor, Voting Behavior \& Presidential Elections 84 (1975); C. Johnson, Nonvoting AmrRicans (1980) (published by U.S. Dep't of Commerce).

152. Distrust of public officials was a significant current in radical Whig political theory, which played an important role in pre-constitutional American thought. See G. WOOD, THE CREATION OF THE AMERICAN RYPUBLIC: 1776 1787 (1969):

The theory of government that the Americans clarified in their reading and discussion possessed a compelling simplicity: politics was nothing more than a perpetual battle between the passions of the rulers, whether one or a few, and the united interests of the people-an opposition that was both inevitable and proportional.

Id. at 18. Radical Whigs doubted that this dualism could be overcome by any representational process.

Power in the hands of an elected ruler, no less than in a hereditary one, was still presumed to exist autonomously. . . . Thus mere popular election, in place of royal appointment or hereditary succession, was no substantial guarantee against tyranny. . . . The Americans knew they had among themselves "tyrants enough at heart"; and although their governors would now be elected periodically by the people or their representatives,-so intoxicating and corrupting was the power of ruling that an elected magistrate was actually no less to be dreaded than an hereditary one.

Id. at 135. The distrust of elected representatives and fear of corruption through the process of representation remain important strands of popular American perceptions of politics. They are nonetheless substantially ignored in interventionist theories of judicial review. 
to make her private life public. Paradoxically, the promotion of private values in public forums corrupts those values. ${ }^{153}$

Thus, one cannot depend on the political process alone to prevent public invasion of private values. Unfortunately, however, the relationship between context and preference suggests that other potential mechanisms for establishing the boundary are likely to produce similar distortions. Because any mechanism to establish and police the boundary must itself be either public or private, it is likely to produce the very interpenetration that the boundary is designed to avoid.

Consider, for example, the problem posed by Moore v. City of East Cleveland.154 An East Cleveland housing ordinance prohibited Mrs. Moore from living with two of her grandchildren who were first cousins. Striking down the statute, Justice Powell observed for a plurality that the law was not entitled to "the usual judicial deference" because the City had undertaken "intrusive regulation of the family."15s When the government limits "choices concerning family living arrangements, this Court must examine carefully the importance of the government interests advanced and the extent to which they are served by the challenged regulation." 138

The difficulty with Powell's position is self-evident. The East Cleveland ordinance purported to respect fully "choices concerning family living arrangements." It simply defined "family" to exclude the living arrangement of the Moore household. Thus, a protection of "family" rationale supports the plurality decision only if supplemented by a rule that precludes public definition of the boundary between "family" and

153. Consider, for example, the recurring spectacle of American politicians making public use of their private lives. Elected officials who publicly proclaim their affection for their spouses or permit "exclusive interviews" about "intimate" details of their family life are not expressing true private values. The very act of making their private lives public corrupts private values and transforms them into something quite different. This phenomenon is not restricted to politicians who make strategic use of their "private" lives. The recent experience of former Senator Paul Tsongas illustrates that even good faith efforts to make public our private values necessarily transforms those values. Informed that he was suffering from a life-threatening illness, Tsongas apparently came to a realization that he was neglecting the private side of his personality and left public office in order to give greater attention to private values. See Tsongas Votes for Family and Home, Boston Globe, Jan. 13, 1984, at 1, col. 1. Even if there were no more to the story, it is surely revealing that $T$ songas felt called upon to leave public office in order to have a meaningful private life. The aftermath of the public announcement of his decision is even more revealing. For a brief period, Tsongas' family became a topic of public discussion. Feature stories about his family life, interviews with his spouse, and pictures of him "relaxing" with his family appeared in countless newspapers. See, e.g., All for the Family: Paul and Niki Tsongas Are Making Up for Lost Time, Boston Globe, Mar. 27, 1984, at 23, col. 3; Paul Tsongas $\mathbb{E}^{2}$ the Choice of a Lifetime, Washington Post, Feb. 1, 1984, at C1, col. 5. Paradoxically, his very assertion in a public forum of his desire to lead a private life at least briefly destroyed his ability to maintain a life that was private in any meaningful sense.

154. 431 U.S. 494 (1976).

155. Id. at 499 .

156. Id. 
"nonfamily." Of course, if public institutions were given unfettered power to define this boundary, they could use it to occupy space that should be reserved for private decisions and special relationships. But it is no more satisfactory to allow each individual or group total freedom to define "family." Such private definitions might invade the public space where individuals are not entitled to special treatment, but must restrain their non-utility maximizing behavior. For example, if the East Cleveland neighborhood were permitted to define itself as a "family," it could be freed of the obligation to treat all its members with impersonal equality and beneficence and, therefore, might be protected in its assertion of the right to exclude Mrs. Moore. ${ }^{152}$ Indeed, the East Cleveland plurality itself recognized the need for limits on private definitions of "family" when it reaffirmed and distinguished the Court's prior decision in Village of Belle Terre v. Boraas, ${ }^{168}$ which upheld the constitutionality of a public definition in a zoning ordinance that prohibited "families" of wholly unrelated individuals from living together.

This recurring problem of boundary definition threatens to make the entire enterprise of constitutional adjudication incoherent. Consider, for example, the problem of finding an appropriate definition of "religion" for purposes of the free exercise clause of the First Amendment. Presumably, the clause is premised on the notion that religious practice and belief should be left in the private sphere. Unless we are prepared to permit private vetoes of all collective decisions, however, we must place some public limit on what counts as a "religion."159 The need for this publicly defined boundary creates inevitable controversies over what are and are not "real" religions. Public institutions thus must make judgments about whether deviant sects comport with the officially adopted criteria for religious faith-in the name of protecting religious belief from government interference! $!^{180}$

157. See Burt, The Constitution of the Family, 1979 Sup. CT. Rev. 329, 390-91; $c f$. M. Walzer, SPHERES OF Justice. 36-39 (1983) (discussing nature of the neighborhood).

158. 416 U.S. 1 (1973).

159. Compare, e.g., United States v. Seeger, 380 U.S. 163, 176 (1965) (conscientious objector statute construed to include belief that "occupies in the life of its possessor a place parallel to that filled by" the orthodox belief in God) with Wisconsin v. Yoder, 406 U.S. 205, 216 (1972) ("II]f the Amish asserted their claims because of their subjective evaluation and rejection of the contemporary secular values accepted by the majority, much as Thoreau rejected the social values of his time and isolated himself at Walden Pond, their claims would not rest on a religious basis."). For a summary of the secondary literature, see Constitutional LAw, supra note 2, at 1369-73.

160. Defining "religion" broadly in order to avoid this difficulty, see, e.g., L. TRIBE, AMERICAN CONSTrTUtionAl. LAW 826-28 (1978), only forces its reemergence in the guise of determining the sort of state interest that is sufficient to overcome the religious claim. Consider Goldman v. Weinberger, 106 S. Ct. 1310 (1986), where a sharply divided Court rejected a free exercise challenge to the application of an Air Force regulation prohibiting personnel from wearing headgear while indoors. Plaintiff was an orthodox Jewish officer who was disciplined for wearing a yarmulke. In his spirited dissent, Justice Brennan attempted to confront a "slippery slope" argument premised on the possibil- 
A final example, drawn from the jurisprudence of reproductive autonomy, demonstrates that the problem becomes still more complicated when there is a need to police the boundary among private groups. Roe $v$. Wade ${ }^{\mathbf{1 6 1}}$ suggests that a woman's decision whether to terminate her pregnancy should be her own. Merely leaving the decision in the private sphere, however, does not necessarily mean that it will be autonomous. If the parents of a pregnant minor attempt to stop her from securing an abortion, it simply will not work to say that "family" decisionmaking should be left in the private sphere, as both sides advance conflicting claims based on the autonomy of family. Nor is it clear how public institutions can avoid policing this boundary because whatever those institutions do must result in victory by one of the private parties. This dilemma has, once again, caused the Court to turn its own doctrine on its head: The Roe Court's insistence that the abortion decision remain in the private sphere has been transmogrified into a constitutional requirement that the states provide access to a public forum for review of that decision. ${ }^{\mathbf{1 6 2}}$

\section{B. Boundaries Without Maps}

Unfortunately, the boundary problem is built into any legal doctrine that rests on enforceable maintenance of separate spheres. ${ }^{163}$ Indeed, the intractability of the problem may add weight to the arguments against a separate spheres approach and in favor of a more complete integration of conflicting values.

ity of free exercise claims for less familiar religious attire. After pointing out that turbans, saffron robes, and dreadlocks were not before the Court, Brennan conceded that "a reviewing court could legitimately give deference to dress and grooming rules that have a reasoned basis in, for example, functional utility, health and safety considerations, and the goal of a polished, professional appearance." Id. at 1319 (citation omitted). Justice Stevens' response in his concurring opinion perfectly states the boundary dilemma:

The very strength of [petitioner's] claim creates the danger that a similar claim on behalf of a Sikh or a Rastafarian might readily be dismissed as "so extreme, so unusual, or so faddish an image that public confidence in his ability to perform his duties will be destroyed." If exceptions from dress code regulations are to be granted on the basis of a multifactored test $[$,$] ...$ inevitably the decisionmaker's evaluation of the character and the sincerity of the requestor's faith-as well as the probable reaction of the majority to the favored treatment of a member of that faith-will play a critical part in the decision.

Id. at 1316 (quoting Justice Brennan's opinion).

161. 410 U.S. 113 (1973).

162. In Bellotti v. Baird, 443 U.S. 622 (1979), a plurality of the Court held:

[I] the State decides to require a pregnant minor to obtain [parental] consent to an abortion, it also must provide an alternative procedure whereby authorization for the abortion can be obtained.

A pregnant minor is entitled in such a proceeding to show . . . that even if she is not able to make this decision independently, the desired abortion would be in her best interests.

Id. at 643-44 (citations omitted); see also Planned Parenthood Ass'n v. Ashcroft, 462 U.S. 476, 490-95 (1983).

163. See generally Katz, Studies in Boundary Theory: Three Essays in Adjudication and Politics, 28 Buffalo L. REv. 383 (1979). 
Because I think that there is no solution to the problem, it would be foolish to argue that judicial review provides one. But I do want to make a more modest claim: Judicial enforcement of constitutional rights can best be understood as our society's imperfect effort to deal with the boundary problem, particularly in the public/private context. Courts are suited to play a mediating role between public and private spheres because they are the most private of our public institutions. Their ambivalent position is built into the way judges are selected, the way they are permitted to lead their lives, and the very nature of judging as it has evolved in American legal culture.

Whether in fact these institutional arrangements mean that judges faced with the problem of boundary maintenance react differently from other government actors is an empirical question of some complexity that I do not intend to answer here. It may be that the institutional arrangements shielding judges from the forces influencing those in the legislative and executive branches have relatively little impact. If this is true, judicial review itself is largely unimportant. Without taking a position on that issue, I want to argue merely that to the extent that judicial review matters, it matters because of institutional arrangements that encourage judges to be in touch with both universalist and particularist values. To the extent that judges respond to those arrangements, they pose the least risk of invading either sphere in the process of maintaining the boundary between them.

The most obvious way in which judges are caught between the public and private spheres relates to their selection and tenure. Judges are public officials with public responsibilities. There is a sense in which their nominations and confirmations are political events; but there are also important, albeit vague and controversial, constraints on the permissible political oversight of the nominating process. Although investigations of general competence (whatever that means) and "judicial philosophy" (an even vaguer term) are permissible, use of "litmus tests" based on inquiry into decisions in particular cases is not. ${ }^{164}$ The selection process imposes some public check on the type of people who become judges, yet leaves judges free of prior, publicly coerced commitments that might interfere with the expression of private values in deciding future cases.

The etiquette of nomination and confirmation is not fully worked out and remains controversial. Moreover, to the extent it is worked out, the

164. For a statement of the conventional view, see L. Tribe, God Save This Honorable Court (1985). Tribe argues that "[e]ach Senator, as well as the President, should determine the outer boundaries of what is acceptable in terms of a potential Justice's constitutional and judicial philosophies-a candidate's substantive views of what the law should be, and the candidate's institutional views of what role the Supreme Court should play." Id. at 93. On the other hand, he insists that "[l]itmus tests that seek out a candidate's unswerving commitment to upholding or reversing a particular legal precedent are simply not an acceptable part of the appointment process." Id. at 97. 
rules border on self-contradiction. One wonders, for example, why anyone would care about "judicial philosophy" apart from what it says about how a nominee will vote in particular cases or, indeed, what "judicial philosophy" could possibly consist of other than a predisposition to vote certain ways in certain cases. ${ }^{165}$ From the perspective of boundary maintenance, however, one would not want these contradictions to be resolved. Any resolution of them would result in dominance of either the public or private sphere.

Once in office, judges remain uniquely shielded from political pressures that undermine the ability of other public officials to balance particularist and universalist values. Traditionally, the life tenure of federal judges has been thought to allow them to promote minority or long term interests free from popular pressures of the moment. ${ }^{168}$ But in fact, political insulation may be a necessary precondition to a decisionmaking process that accurately reflects majority sentiment, free from the artificial inflation of public values produced by the electoral process. Judges who need not stand for election are less likely to have their decisions distorted in favor of an electorate in which publicly oriented voters are disproportionately represented or by the fact that voting may cause people to think in universalist terms. ${ }^{167}$

The conflict between universalist and particularist norms is also built into the very act of deciding constitutional cases, at least as that institution has developed in this country. In recent years, two of the central debates about the legitimacy of constitutional review have concerned the constraining force of the constitutional text and of "neutral principles." The

165. Professor Tribe argues that the Senate has a special duty not to confirm Supreme Court nominees appointed solely because they "are found acceptable by a specific political or moral constituency." Id. at 98. A nominee's adherence to such a "specific presidential agenda" reflects, in Tribe's view, "an unjudicious commitment not to a coherent constitutional philosophy, but to a slogan or even the outcome of a single case." Id. at 98 . Nominees holding "knee jerk attitudes" towards gun control, capital punishment, or right to life apparently flunk this test. See id. at 97 . Yet Tribe also wants to insist that adherence to the outcome of certain cases can function as an appropriate litmus test. Thus, "[s]ome constitutional landmarks are so crucial to our sense of what America is all about that their dismantling should be considered off-limits and candidates who would be at all likely to upend them should therefore be considered unfit." Id. at 94. Apparently, Brown v. Board of Education, 347 U.S. 483 (1954), the reapportionment and incorporation decisions, and the constitutional protection of property and contract from "[a] communist notion of regimented social and economic equality" fall into the latter category. Id. at 94-96. Presumably, Professor Tribe stands ready to provide expert consultation to those less adept than he at distinguishing between nominees with "knee jerk attitudes" and those sharing "our sense of what America is all about."

166. See, e.g., L. Tribe, AMERICAN Constitutional. LAw 48 (1978).

167. See supra text accompanying notes 151-52. Moreover, the fact that judges are exempted from electoral politics means that they themselves are permitted to have private lives. Judges may therefore be able to understand, in a way that most other public officials cannot, the pull between universal beneficence and particularized special relationships. Because the conflict between these two impulses is more likely to be a real force in their own lives, they may be better equipped to keep in balance a regime of institutionalized conflict between private and public values. 
need for a mediating institution that encapsulates the contradiction between our universalist and particularist selves throws a different light on both these debates, and suggests that the failure to resolve both debates contributes to the legitimacy of judicial review.

Consider first the appropriate role for the constitutional text. Although the constraining force of the text was traditionally believed to be crucial to the legitimacy of judicial review, ${ }^{168}$ an important legacy of utilitarian skepticism $^{169}$ is that this view no longer seems plausible. All of the key concepts in the constitutional text are, in fact, radically indeterminate. ${ }^{170}$ Moreover, the instability of meaning over time, ${ }^{171}$ the inherent difficulty of discerning collective intent, ${ }^{172}$ and the likelihood that at least some framers meant to allow growth and change in the document's meaning ${ }^{173}$ doom an interpretation based on intent. Finally, even if the original intent were determinate and discoverable, the question remains why anyone would think that modern disputes should be resolved by what a small group of elite white males thought two hundred years ago. ${ }^{174}$

The collapse of textualism has created something of a crisis in modern constitutional debate. Today, one would be hard pressed to find anyone in the mainstream of American politics who favors reversal of all Supreme Court decisions that exceed the power conferred by a reasonable reading of the constitutional text. ${ }^{175}$ Oddly, this practical victory for nontextualist

\footnotetext{
168. For the classic statement, see United States v. Butler, 297 U.S. 1 (1936):

It is sometimes said that the court assumes a power to overrule or control the action of the people's representatives. This is a misconception. . . . When an act of Congress is appropriately challenged in the courts as not conforming to the constitutional mandate the judicial branch of the Government has only one duty,-to lay the article of the Constitution which is invoked beside the statute which is challenged and to decide whether the latter squares with the former.
}

Id. at 62 .

169. See supra text accompanying notes 97-116.

170. See, e.g., R. Dworkin, supra note 53, at 133-37 ("vague" constitutional guarantees such as equal protection are appeals to underlying moral concepts, not embodiments of specific prohibitions).

171. See, e.g., Tushnet, supra note 77, at 793-804.

172. See, e.g., Dworkin, supra note 122, at 482-83.

173. See, e.g., J. ELY, supra note 27, at 22-30; R. Dworkin, supra note 53, at 133; Powell, supra note 122.

174. See Tushnet, supra note 77, at 787-89.

175. For example, Attorney General Edwin Meese has generated considerable controversy by advocating a rigidly textualist approach. See, e.g., "Meese Attacks Supreme Court Religion Rulings," Los Angeles Times, July 10, 1985, at 3, col. 1. Yet he has never suggested that Brown v. Board of Education, 347 U.S. 483 (1954), should be overruled, although the textual and historical support for the holding is dubious at best. See, e.g., R. Berger, Government by Judiciary: The TransforMATION OF THE. FOUR'TEENTH AMENDMENT 123-25, 133 (1977). And one wonders what sort of textualist defense he could possibly mount for Bolling v. Sharpe, 347 U.S. 497 (1954) (school segregation in District of Columbia violated due process clause of Fifth Amendment), which was based upon a constitutional provision enacted at a time when blacks were held as slaves. As Professor Perry has demonstrated, strict adherence to the principle that judicial review should be limited to enforcement of values constitutionalized by the framers would result in the overruling of most of the modern Court's "human rights" decisions. See M. PERRY, supra note 53, at 2. 
approaches has been coupled with an increasingly shrill rhetorical insistance that textualism is the only basis for judicial legitimacy. ${ }^{178}$

An appreciation of the Supreme Court's role in boundary maintenance between the public and private spheres suggests a way to understand this paradox. The indeterminacy of the text is a necessary precondition for the legitimacy of constitutional review. Some commentators have argued that the text, or at least certain portions of it, should bind future generations because it was written during rare moments in our history when most of the country was politicized. ${ }^{177}$ In this view, the Constitution represents as pure an articulation of our public universalist values as we are likely ever to get. But, precisely because the Constitution is a public document articulating public values, it would be undesirable to let the constitutional text alone mark the boundary between the public and private spheres. Allowing a public document to determine the boundaries of private power would build into the system a bias in favor of public values.

It hardly follows, however, that an unambiguous victory for nontextualism would be desirable, as a totally nontextualist approach would risk private invasion of public values. Judges who feel no necessity to justify their decisions according to public values might become the mouthpiece of special interests and sectarian prejudices. The continuing significance of textualist rhetoric in public debate reflects a healthy awareness of this danger. The conflict between the public rhetoric of textualism and what judges inevitably do when they wrestle privately with an indeterminate text leaves them in an impossible position. From the perspective of boundary maintenance, it is desirable that they remain there. Any clear resolution of the conflict would prevent judges from fulfilling their mediating role.

The same pattern of unresolved conflict is discernible in the debate over neutral principles. Nineteenth century formalism was marked by a belief that law is a carefully worked-out series of deductions from noncontroversial general principles. ${ }^{178}$ For anyone with modern sensibilities, this view of the legal process, like the view that sees constitutional adjudication as no more than the explication of text, seems impossibly naive. Rules, like

176. See, e.g., "Meese Attacks Supreme Court Religion Rulings," supra note 175.

177. The argument is made most forcefully by Ackerman, supra note 33 , who argues that,

[b]y providing a higher lawmaking system, the American Constitution succeeds in constituting something more than a government in Washington, D.C. It constitutes a system of political meanings that enable all $\Lambda$ mericans to indicate the rare occasions when they mean to present themselves to one another as private citizens, and mark them off from the countless ordinary occasions when they are content to understand themselves as merely private citizens-for whom political life is but one of many diversions in the ongoing pursuit of happiness.

Id. at 1042 (emphasis in original).

178. See, e.g., G. White, Tort Law in AMerica: AN INTEllectual. History 23-37 (1980). 
text, are necessarily indeterminate, ${ }^{179}$ and legal reasoning is therefore inductive, particularistic, and pragmatic. The demise of formalism, like the demise of textualism, has created problems for those worried that an unrestrained judiciary might fail to act in the public interest. Rule skepticism leaves judges free to decide individual cases without limiting their freedom in future cases. Without a meaningful requirement to generalize, judges are left free to create special "rules" for particular, favored litigants, thereby threatening the public values associated with universality and impersonal beneficence.

The "neutral principles" paradigm is an effort to rescue judging from this dilemma. ${ }^{180} \mathrm{~A}$ "neutral principles" approach recognizes the inductive, particularistic character of judging as both a virtue and a necessity. By focusing their attention on the facts of particular cases, judges can avoid the sterile forces of abstraction and reification. They can, in other words, bring private values, associated with the particular litigants before them, to bear on their decisions. ${ }^{181}$ Yet these values are held in check by the requirement that, however a case is decided, the judge must be willing to formulate a more general principle that explains the result in the case before him. One of the things that makes this principle "general" is that it is intended to apply to anonymous individuals without real personalities and individualized lifestories that might influence intuitions about appropriate outcomes. The neutral principles requirement therefore pushes judges toward the universalist ideal of equality and impersonal beneficence. Of course, when a subsequent case arises, the judge need not always follow the principle. The particular facts of the new case-the force of particularist values-may cause him to abandon it. But if he does so, he must acknowledge that he has abandoned it and formulate a new "neutral principle" that takes into account the new decision.

Others have argued with considerable force that the neutral principles paradigm rests on a contradiction. ${ }^{\mathbf{1 8 2}}$ If the neutral principles are truly

179. See, e.g., Tushnet, supra note 77, at 821-23 and sources cited therein.

180. The seminal statement of this approach is Wechsler, Toward Neutral Principles of Constitutional Law, 73 HARv. L. Rrv. 1, 15-17 (1959).

181. See E. LEvi, An InTroduction to Ligal Reasoning (1948):

[T] he kind of reasoning involved in the legal process is one in which the classification changes as the classification is made. The rules change as the rules are applied. More important, the rules arise out of a process which, while comparing fact situations, creates the rules and then applies them. . . . The categories used in the legal process must be left ambiguous in order to permit the infusion of new ideas. And this is true even where legislation or a constitution is involved. The words used by the legislature or the constitutional convention must come to have new meanings. Furthermore, agreement on any other basis would be impossible. In this manner the laws come to express the ideas of the community and even when written in general terms, in statute or constitution, are molded for the specific case.

Id. at 3.

182. The best critique is Tushnet, supra note 77 , at $804-24$. 
constraining, then judging cannot have the inductive character claimed for it, and judges will not be able to depart from the rules when they contradict particularist values. On the other hand, if the principles are not truly constraining (because they are so vague as to be meaningless, or because rules by their nature cannot constrain, or because the rule can always be overthrown when it becomes inconvenient to follow it), then the generality requirement does nothing to legitimate the exercise of judicial power.

What critics of neutral principles fail to understand, however, is that any effort to bring to bear both private and public values on a decisionmaking process will necessarily end in contradiction. People simply hold different, contradictory beliefs when they think about issues from particularist and universalist perspectives. One result will therefore seem right if the judge thinks about the problem ex post and cares about doing justice to the particular individuals before him. Another result will seem equally right if the judge thinks more broadly about the ex ante incentive effects of his decision on anonymous individuals and whether the rule to be derived from the case will maximize overall utility. Since these views are necessarily contradictory, it follows that there cannot be a unified theory of boundary maintenance. Only a judge who is sensitive to the contradictory demands of public and private values-who is caught between the desire to do "justice" to the particular, real litigant and the desire to formulate a general rule to maximize utility for the remaining faceless multitude-can be trusted to maintain the boundary between the two spheres without invading either.

\section{Boundary Maintenance and the Dilemmas of CONSTITUTIONALISM}

\section{A. New Solutions}

In this final section, I want to explore the extent to which a theory premised on conflict between private and public spheres actually does the work claimed for it. More specifically, does the theory resolve the nagging dilemmas that have plagued constitutional thought for fifty years? I conclude that the theory successfully resolves some of these difficulties, but at the price of creating new, and in some ways more serious, problems at a deeper level.

A theory of boundary maintenance explains both the dilemma of government versus nongovernmental power and the dilemma of universalist versus particularist values. The theory suggests that we need a government sphere to nurture universalist values, but that this very requirement implies the need for a separate nongovernmental sphere within which particularist choices can be made. 
Moreover, the theory is strikingly successful in resolving the difficulties that first produced, and ultimately destroyed, the Carolene Products compromise. Because the theory does not rest on a claim that particular decisions or activities are "naturally" public or private, it is threatened by neither rule nor value skepticism. On the contrary, doubts about the constraining force of rules and the logical defense of values are important components of a boundary maintenance approach. Any determinate rule, text, or doctrine that successfully constrained judges would risk the supremacy of either public or private values and would therefore be undesirable. Judges are not constrained by text or doctrine, but by the ongoing conflict between universalist and particularist values in their own work and lives. Because these values are necessarily contradictory, it is hardly surprising that they are logically indefensible. The advantage of a theory premised on conflict, rather than on reconciliation, is that a logical defense of values becomes unnecessary and undesirable. Any such defense must presuppose some final resolution of or choice between contradictory demands, whereas the theory claims that a whole person must forever make contradictory choices depending upon the sphere within which she is choosing.

A boundary maintenance approach also resolves other anomalies associated with judicial review. Pluralist and civic virtue theories face serious difficulty in explaining how public accountability is advanced by granting power to an institution deliberately shielded from public pressure. ${ }^{183} \mathrm{~A}$ boundary maintenance theory avoids this difficulty by arguing that a system of total public accountability is undesirable because it fails to take into account private preferences. The theory thus provides a plausible rationale for the Supreme Court's persistent defense of private power.

\section{B. New Problems}

Although the theory may resolve some of the old contradictions by relating the problem of intervention to the problem of private and public values, it also creates new contradictions on a deeper level that are as serious as those it resolves. Each of these contradictions, I believe, is in fact a manifestation of a single contradiction that can be stated simply: The theory, if true, deprives us of a firm place from which we can assess its validity. The theory derives much of its power from the assertion that people do not have unitary or consistent preferences. They are torn between contradictory universalist and particularist urges, and their choices between conflicting options are irreducibly context dependent. ${ }^{184}$ But if

183. See supra Section I.A.

184. See supra Section I.C.1. 
this is true, then there is no reason to suppose that we will be able to transcend context in evaluating the theory or the institutions that the theory purports to justify. The theory can thus be turned on itself and used to deny the very possibility of this, or any other, constitutional theory.

We can begin to explore these difficulties by contrasting universalist and particularist critiques of the theory. Some critics who are attracted to universalist values might argue that the last thing we need at this stage of our political development is a theory justifying legal restraints on government intervention in the private sphere. In this age of deregulation, widespread disenchantment with big government, and growing inequalities in wealth and power in the private sphere, these critics might contend there is little danger that our political institutions will not take sufficient account of particularist values. On the contrary, universalist concerns are everywhere in retreat.

In some measure this criticism rests on a failure to understand that the boundary maintenance theory has two component parts which must be considered together. It may be true that our present government poses no serious threat to particularist values. But that is precisely because our present government is insufficiently universalist in orientation. The theory insists that, faced with such a government, judicial review should be used to push representative institutions toward universalism and that if it succeeded in this endeavor, then a fully universalist government would pose a threat to particularist values.

This response does not fully answer universalist critics of the theory. A universalist might respond by reintroducing the question of context. It may be true that in some hypothetical context where government functioned very differently, there would be a need to check its invasion of the private sphere. In actuality, we require a theory of constitutional law for our own time; currently, a theory that provides rhetorical support for those defending vast accumulations of private power and wealth is likely to produce nothing but mischief.

Ironically, while not satisfying critics with a universalist bias, the theory is also likely to be equally unsatisfactory to those attracted to particularist values. Once again, the difficulty relates to context and to shortcomings inherent in efforts to manipulate context. Specifically, to preserve particularist values in uncorrupted form, the theory requires at crucial points an extremely fragile precommitment to self-deception. As noted above, ${ }^{185}$ a precommitment to deprive government of power over "private" decisionmaking is necessary, since otherwise a fully universalist government would be forced to advance universalist justifications for allowing

185. See supra text accompanying notes 82-92. 
particularist decisions, thereby destroying their particularist character. There was a time when this disempowerment was accomplished by a world view that treated certain questions as "inherently" or "naturally" private and, therefore, immune from government interference. Although remnants of this approach survive, our ability to fool ourselves with it was severely damaged by the New Deal and the destruction of the old natural law limitations on government power that came in its wake.

In some measure, we have replaced this technique with a precommitment to secrecy in the particularist sphere. ${ }^{186}$ If the government does not "know" what is going on, then it need not provide a universalist justification for it. Unfortunately, this form of self-deception is extremely fragile. It is not clear that self-deception in this sense-deciding not to know what we, in fact, do know-is ever a coherent strategy. Moreover, even if we could succeed in deliberately forgetting what is happening in the particularist sphere, government must still establish the institutions that cause it to forget. A fully universalist government would need to offer universalist justifications for these institutions, thereby corrupting particularist values once again, this time at one step removed. ${ }^{187}$

Moreover, it is not clear that we can deliberately forget, or that, even if we could, we would want to develop this capacity for deliberate selfdeception. No amount of secrecy surrounding particularist decisions can erase the nagging reality that those decisions are taking place and that government could do something about them. The boundary between public and private is thus constantly threatened by those who refuse to play the game, who stubbornly insist on making us see the suffering on the other side of the wall we have erected. Breaching the wall of selfdeception vastly increases the risk of corrupting particularist choices by making their legitimacy contingent upon the availability of universalist justifications for them.

In fact, evidence of such corruption is all around us. For example, the Court has endorsed public accommodation of private religious faith. Because the accommodation must be defended in a public forum, the Court has felt compelled to make universalist arguments for its position, arguments that tend to destroy the very values being accommodated. Thus, deeply religious symbols like the crèche become, for the Court, merely a portion of a display with plastic reindeer, exhibited to advance universal-

186. See supra text accompanying notes 85-87.

187. This difficulty is part of a larger problem posed by all precommitment strategies. These strategies are premised on a meta-choice to privilege choices made in one context over those made in another. But since the meta-choice itself must be made in some context, it is unclear why it should enjoy privileged status. See Ulysses, supra note 74, at 41-42. Thus, even when we act in advance to establish a public or private context for decisionmaking, we must necessarily be acting in a public or private context, and that context itself will bias our decision regarding the choice of context. 
ist, secular objectives. ${ }^{188}$ Similarly, the Court's public recognition of the need for an autonomous sphere for private family decisionmaking has, on occasion, resulted in a fundamental recharacterization of the family. A public defense of the family transforms that institution from a means of nurturing love and special relationships for their own sake into a utility maximizing method for controlling socially harmful deviant behavior. ${ }^{189}$

Thus, the boundary maintenance theory arguably gives us the worst of both worlds. By defending the integrity of a private sphere, it may obstruct desirable universalist restraints on the exercise of private power. Yet by relying upon a vulnerable precommitment to self-deception, it may also corrupt the very particularist values it purports to defend.

Ultimately, what is most troubling about the theory is not that it is subject to these particularist and universalist critiques, but that it denies the possibility of any normative judgments about itself. Both the particularist and the universalist critiques begin with an assumption about the orientation of the critic. If the theory is correct, however, all critics who are whole persons are necessarily both particularist and universalist in orientation, with their preferences dependent on context. The plausibility of the critiques, as well as of the theory itself, thus turns on a different self-deception-the belief that the authorial voice advancing the theory

188. See Lynch v. Donnelly, 465 U.S. 668 (1984). The need to advance secular arguments for a municipality's inclusion of a crèche in a public Christmas display on the one hand, without debasing its religious significance on the other, led the Lynch Court into predictable contradiction. Writing for the majority, Chief Justice Burger rejected the trial court's finding that the inclusion of the crèche had no secular purpose and constituted "some kind of subtle governmental advocacy of a particular religious message." Id. at 680 . But unambiguous reliance on the putative secular purposes of the display would rob the crèche of its religious significance, thereby destroying the very religious values the Court sought to accommodate. Therefore, while rejecting the possibility that the crèche served religious purposes, the Chief Justice also felt compelled to disassociate himself from the view that it served no religious purposes: "[N]one who sense the origins of the Christmas celebration would fail to be aware of [the display's] religious implications. That the display brings people into the central city, and serves commercial interests and benefits merchants and their employees, does not . . . determine the character of the display." Id. at 685.

189. As Professor Burt has forcefully argued, this is the only way to reconcile the Court's otherwise contradictory treatment of issues of parental control in cases such as Parham v. J.R., 442 U.S. 584 (1979), and Ingraham v. Wright, 430 U.S. 651 (1977). See Burt, supra note 157, at 332-45. In Parham, the Court refused to accord full-scale hearings to children whose parents wished to confine them to mental institutions. Although acknowledging the liberty interest in avoiding unjustified hospitalization, the Court rejected "[t]he statist notion that governmental power should supersede parental authority in all cases because some parents abuse and neglect children . . . " 442 U.S. at 603 (emphasis in original). Yet in Ingraham, the Court approved the use of corporal punishment in the schools even in the face of parental objections:

Although the early cases viewed the authority of the teacher as deriving from the parents, the

concept of parental delegation has been replaced by the view . . . that the State itself may impose such corporal punishment as is reasonably necessary "for the proper education of the child and for the maintenance of group discipline."

430 U.S. at 662 (citation and footnote omitted). As Professor Burt writes, the principle underlying these and other cases is "not that parental authority as such warrants respect. Rather, the authority over children that commands constitutionally mandated respect is that which is backed by force clearly promising effective control over children's disruptive impulses." Burt, supra note 157, at 338 . 
and its possible criticisms is "neutral," disembodied, and context-less. The anonymous, grey prose of law journal writing promotes this illusion. It is, of course, an illusion. Law journal writing (and reading)-like voting, constitution writing, or family conversation-is itself a context that, if the theory is correct, influences choice. And there is no more reason to privilege this context than any other.

I have no desire to minimize or explain away these difficulties. Nonetheless, it would be unfair to suppose that these are problems that uniquely afflict a boundary maintenance approach. They are the difficulties faced by any post-Realist constitutional theory. Recall, for example, that the Carolene Products compromise ultimately collapsed because Legal Realism left us similarly skeptical of our ability to articulate any "natural," "principled," or disembodied division between public and private. In a world without Lochner, all constitutional theories-including the skeptical theory propounded by Justice Holmes himself-must contend with the corrosive force of the skepticism that Holmes bequeathed to us.

It is worth emphasizing, therefore, that as long as the Lochner approach remains implausible, the real competitor to boundary maintenance is not another legitimating theory. The serious challenge comes from those who reject theory altogether and would have us embrace nihilism. It would surely be wrong to dismiss such an approach out of hand. There is an undeniable attraction to the idea of simply "doing" constitutional law without bothering with justifying theory.

Using such an approach, we might opt for a model that made no effort to specify in advance either the boundaries between a public and a private sphere or an agreed-upon method for establishing the boundaries. Instead, we could simply allow unrestrained warfare between public and private. The corruption of public and private values might be avoided if we stopped trying to accommodate public and private spheres. ${ }^{190}$ For example, private religious values would no longer be debased if the state simply punished religious dissenters without attempting public toleration of private values. Public punishment takes private values seriously by acknowledging, in a way that toleration does not, the ultimate irreconcilability of public and private choices. ${ }^{191}$ Similarly, a model based on conflict rather

190. The Court may in fact have already stopped trying in some cases. See Cover, The Supreme Court, 1982 Term-Foreword: Nomos and Narrative, 97 HARv. L. Rev. 4, 67-68 (1983).

191. Dean Ely has made an analogous point with regard to certain forms of political protest which would lose their meaning if they were tolerated. "Had there been no law prohibiting draft card burning .... [a protester] might have attracted no more attention than he would have by swallowing a goldfish." Ely, Flag Desecration: A Case Study in the Roles of Categorization and Balancing in First Amendment Analysis, 88 HARv. L. Rev. 1482, 1489-90 (1975). Dean Ely's observation puts a somewhat sinister cast on Justice Brandeis' famous defense of the First Amendment on the ground that repression "menaces stable government." Whitney v. California, 274 U.S. 357, 375 (1927) (Brandeis, J, concurring). See also T. EMERson, The System of Freedom of Expression 7 
than accommodation might better advance public universalist values. It may be a mistake to suppose that any tinkering with the constitutional balance between government and nongovernmental spheres will make our society appreciably more egalitarian. Conceivably, governmental institutions freed of constitutional constraints might adopt a program of redistribution. But this remains unlikely because the very private power we would wish to control would result in unequal access to political institutions, access that can be utilized to stymie any redistributive program. ${ }^{192}$ Thus, it is at least possible that if serious redistribution is ever achieved in the United States, it will not be because people accept inherited social arrangements as embodied in existing constitutional doctrine or theory, but because people are willing and able to overthrow those arrangements. ${ }^{193}$

It follows that both universalists and particularists might well prefer conflict to accommodation, and would think it foolish to look to any constitutional theory to satisfy their objectives. But the rub is that Legal Realism deprives us not only of a theory, but also of the possibility of doing without a theory. The lesson of Miller $v$. Schoene ${ }^{194}$ is that all actions-and all inactions-have consequences, and that there is no refuge from the obligation to choose. Thus, even if it were true that unrestricted conflict between public and private would produce "desirable" outcomes, one needs some sort of theory to explain why those outcomes, as opposed to others we could also choose, are in fact desirable. The very effort to defend an atheoretical stance forces us once again into normative judgments which call out for a theoretical defense. Nihilism, too, is a theory that can be turned against itself.

We are left, then, with a final layer of self-deception. We know in some sense that we can never transcend context and that theory is therefore impossible. (And I don't need to be reminded, thank you, that the statement that all statements are context bound is, itself, a context bound statement.) But we must either act or fail to act, and either course requires

(1970) ("Freedom of expression ... provides a framework in which the conflict necessary to the progress of a society can take place without destroying the society."). There is an extensive literature on the "repressive" uses of toleration. See, e.g., Marcuse, Repressive Tolerance, in A Critrque of Pure Tolerance: 95-109 (R. Wolff, B. Moore, Jr. \& H. Marcuse eds. 1969).

192. For a good discussion of how deep these difficulties run, and why they are likely to resist reformist solutions, see Levinson, Regulating Campaign Activity: The New Road to Contradiction?, 83 Mich. L. Rev. 939 (1985).

193. My colleague, Mark Tushnet, has put the point this way:

[T] he Stalinism trap asks why a moderately risk-averse person . . . should try to alter the way things are. The answer is clear: conditions of life overall are so near the floor that the cost of falling to the bottom discounted by the likelihood of such a disaster is more than offset by the benefits of alternative forms of social life discounted by the likelihood of their realization.

Tushnet, An Essay on Rights, 62 TEx. L. REv. 1363, 1402 (1984).

194. 276 U.S. 272 (1928). 
justification. So in order to live our lives, there is no escape from telling ourselves that we are able to transcend context so as to make decisions about the kind of future we want to have. ${ }^{195}$

That is why people are likely to go on thinking about constitutional theory. And that is why those who think about it seriously are likely to remain uneasy.

195. As Thomas Nagel has written:

It is necessary to combine the recognition of our contingency, and our containment in the world with an ambition of transcendence, however limited may be our success in achieving it. The right attitude. . . is to accept aims that we can achieve only fractionally and imperfectly, and cannot be sure of achieving even to that extent.

T. NAGFi, ThE: VIFW FROM NOWHERE 9 (1986). 